\title{
Population dynamics and epidemiology of four species of Dendroctonus (Coleoptera: Curculionidae): 100 years since J.M. Swaine
}

\author{
Brian H. Aukema, ${ }^{1}$ Fraser R. McKee, Debra L. Wytrykush, Allan L. Carroll
}

\begin{abstract}
Almost 100 years have passed since J.M. Swaine, the assistant entomologist in charge of Forest Insect Investigations, wrote, "Canadian bark-beetles: a preliminary classification, with an account of the habits and means of control". The goal was to "put into the hands of practical foresters information of inestimable practical value... to prevent the continued loss of timber now being destroyed" by "the most insidious enemies of the forest". In this paper, we celebrate Swaine's pioneering work by summarising the foundational aspects of his early treatise of 1918: the "general habits" of bark beetles, classifications of their behaviour, causes of population increase, and mitigation tactics. In the founding text, Swaine identified all major Dendroctonus Erichson (Coleoptera: Curculionidae) bark beetles found in Canada, although details on life histories were scarce. We summarise current knowledge of the life histories and population dynamics of the spruce beetle, D. rufipennis Kirby; the Douglas-fir beetle, D. pseudotsugae Hopkins; the eastern larch beetle, D. simplex; and address the current range expansion of mountain pine beetle, D. ponderosae Hopkins. We review how aspects of global change, such as invasive species, have altered the population dynamics of certain bark beetles. Finally, we conclude with lessons from two of the many past contributors to bark beetle ecology in Canada, J.M. Swaine and H.A. Richmond.
\end{abstract}

\section{Introduction}

The bark beetles (Coleoptera: Curculionidae: Scolytinae) have long been recognised as key ecological denizens of Canadian forests. These disturbance agents provide a wide array of ecological services; functioning in nutrient cycling, aiding forest succession, mediating watershed hydrology, and affecting aesthetics, recreation, and property values (Safranyik et al. 1974; Richmond 1986). At biome-level scales, recent extensive outbreaks have had an impact on biogeophysical processes such as carbon cycling and sequestration (Kurz et al. 2008; Hicke et al. 2012). Considerations of the multifaceted impacts of bark beetles at multiple scales have broadened considerably since the beginning of the 20th century, when bark beetles were viewed almost entirely as an economic nuisance, and harbinger of potentially dangerous forest fires (Brown 1940).
Through that lens, Mr. J.M. Swaine, the assistant entomologist in charge of forest insect investigations (Fig. 1), set out to compile for the Dominion of Canada a treatise on the "True barkbeetles" during the years of World War I (Swaine 1918). Swaine fastidiously gathered accounts of bark beetle ecologies and methods for control, with descriptions of several new species. Calling Swaine one of "the most inspiring men [with whom] I have ever been associated", Mr. Hector A. Richmond, a pioneering forest entomologist who worked with Swaine in western Canada, noted that following the course of Swaine's activities in the woods was like "tracking the wanderings of an old bear. Every rotten stump or log was torn apart in his quest for various beetles while I, as an observer, would follow and gather up his lost or misplaced tools and equipment" (Richmond 1986). Swaine's enthusiastic investigations and consultations with other early forest professionals

Received 31 July 2015. Accepted 14 November 2015. First published online 11 March 2016.

B.H. Aukema, ${ }^{1}$ F.R. McKee, Department of Entomology, University of Minnesota, 1980 Folwell Avenue, St. Paul, Minnesota, 55108, United States of America

D.L. Wytrykush, A.L. Carroll, Department of Forest and Conservation Sciences, University of British Columbia, 2424 Main Mall, Vancouver, British Columbia, V6T 1Z4, Canada

${ }^{1}$ Corresponding author (e-mail: BrianAukema@umn.edu).

Langor, D.W. and Alfaro, R.I. (eds.) Forest Entomology in Canada: Celebrating a Century of Science Excellence doi:10.4039/tce.2016.5 
Fig. 1. J.M. Swaine, Assistant Entomologist in charge of Forest Insect Investigations, circa 1919. Reprinted from Johnstone (1991).

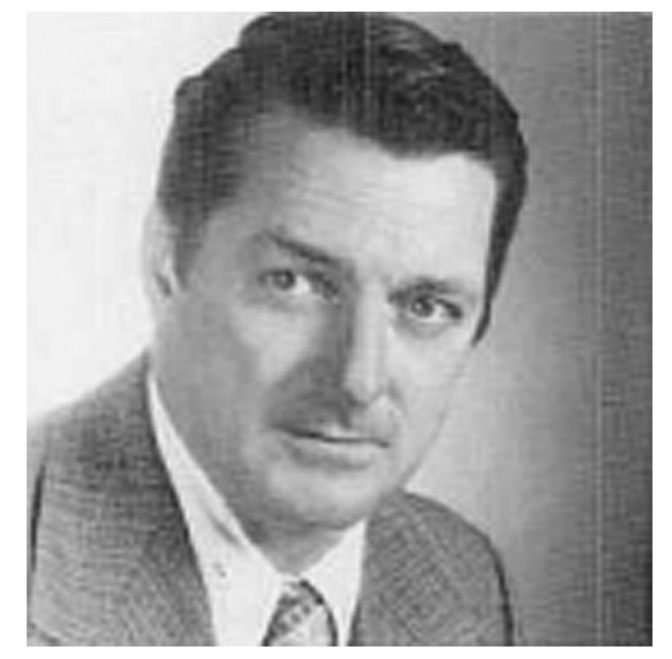

were very fruitful, however. Swaine's excursions culminated in the classic text of 1918, "Canadian bark-beetles: a preliminary classification, with an account of the habits and means of control" that was promptly submitted by Dominion Entomologist and Consulting Zoologist C. Gordon Hewitt for approval to the Honourable Minister of Agriculture. It was hoped that the knowledge in the book would be used to "protect extensive areas that are threatened by the attacks of bark-beetles", which Swaine declared the "chief insect enemies of our coniferous forests" (Swaine 1918).

Swaine's treatise covered 100 species of bark beetles, but focussed on those with potential to cause economic loss, as "the protection and correct utilization of our timber resources is of greater importance than ever from a national and imperial standpoint". Perhaps the most notable achievement of Swaine's first text was the inclusion then of every Dendroctonus Erichson species known to exist within Canada today! In an era devoid of airline, internet, cellular, satellite, and social media coverage - indeed, in an era where the two most critical tools to a forest entomologist were but "a tent and an axe" (Richmond 1986, quoting Swaine) - we may easily take for granted such a historic feat. Swaine also included several other important economic species in his tome, such as western balsam bark beetle Dryocetes confusus Swaine and the four-eyed spruce beetle Polygraphus rufipennis (Kirby).

Reviewing and/or synthesising a century of bark beetle population dynamics in Canada from Swaine's early explorations to the present requires three important admissions. First, much worthy material has undoubtedly been omitted. Certain exclusions are due to strategic choices necessitated by writing a journal article instead of a book. The reader hoping for coverage of past theories of the roles of lance flies (Diptera: Lonchaeidae) in the termination of outbreaks of mountain pine beetle Dendroctonus ponderosae Hopkins may be sorely disappointed (Richmond 1986), although more egregious eliminations exist. More disconcertingly, other omissions are due to inadvertent losses from the national record. During the Depression era of the 1930s, for example, federal bark beetle ecologists in western Canada conducted extensive studies on the reproductive biology of mountain pine beetle, including work on host selection and the roles of competitors, parasites, and vertebrate predators in regulating populations. Unfortunately, results of these investigations were never published due to budget reductions and federal discouragement of publication (Richmond 1986). Our second admission is that we are forest entomologists and not historians. Trained practitioners of the latter discipline may have exercised different editorial choices. Third, similar to Swaine, we focus largely on tree-killing species.

That said, in this work we first honour the heritage of Swaine by summarising the foundational aspects of his early textbook common to many bark beetles: their "general habits", classifications of behaviour, presumed causes of population increase, and tactics to mitigate their effects. Broad advances in the study of the ecology and population dynamics of bark beetles are highlighted. Swaine also provided notes on morphology, hosts, gallery patterns, and damage for a number of economically important species. A full comparison is beyond the scope of the current work; instead, we summarise what is known today regarding the life histories, population dynamics, and management of $D$. rufipennis Kirby, D. pseudotsugae Hopkins, and D. simplex LeConte. Because the population dynamics of $D$. ponderosae have been well described in recent work (Safranyik and Carroll 2006), we 
restrict our treatment of mountain pine beetle to brief comments on range expansion. We discuss how another aspect of global change, invasive species, has altered the outlook of some of the bark beetles mentioned by Swaine. Finally, we close with two adages from Swaine and Richmond that hold true today in the face of a changing world.

\section{Bark beetles and the procurement of host trees}

Bark beetles are cryptic species that feed and reproduce within the phloem and sometimes the outer bark tissues of trees. Swaine termed these insects the "true bark-beetles", excluding those bark beetles that putatively breed in plants of the gourd family; behaviour he jettisoned as "aberrant habits much more common in tropical countries than with us" (Swaine 1918). Bark beetles derive their common name from their life history habits underneath the bark. The subcortical patterns of gallery etchings during reproduction, in tandem with host tree information, are frequently used to identify species. Swaine included plates illustrating gallery formations across a range of taxa before diagnostic illustrations of the insects themselves. Swaine's simple techniques of observing mating and gallery construction behaviour among bark beetles in sandwiches of phloem and bark held between glass plates is still widely used today (Kim and Miller 1981; Taylor et al. 1992; Dodds et al. 2001; Aukema and Raffa 2004).

In a given species of bark beetle, typically one sex is the host-selecting sex (Kirkendall 1983). Pioneering adults will chew through the bark into the phloem tissues before being joined quickly by large numbers of conspecifics. Following mating under the bark, females will begin constructing ovipositional galleries along which eggs are laid. After a feeding period, the larvae pupate at the terminal end of the feeding gallery. New adult beetles emerge by chewing through the bark. In some species, mating occurs under the bark before emerging to procure new hosts (Bleiker et al. 2013). The time spent by adults outside a host is typically very short; only days, as the insects seek new host material (Raffa 2001).

Although the preceding generalised description of bark beetle natural history has not changed substantially in the past century, great strides have been made in understanding the processes by which beetles procure host trees. These discoveries relate to three fields of study: plant-insect interactions, pheromone ecology, and microbiology. As each of these topics is treated elsewhere in this issue, the contributions of each are summarised here in brief.

First, there is now a greater understanding of how bark beetles interact with host tree defences, and how those defences may inhibit or synergise colonisation activities (Raffa and Berryman 1983). Swaine's understanding of insect-host interactions 100 years ago was that bark beetles were primarily confined to "dying bark" and only entered live trees during outbreaks. Today, we have a much broader understanding of the feeding niches of bark beetles within hosts (Ayres et al. 2001), as well as how the suitability and susceptibility of breeding substrate changes with plant defence dynamics (Boone et al. 2011). Beetles seeking to colonise live trees are frequently presented with increased concentrations of resin that pose a chemical and physical barrier to host entry. The tree's defensive response can include rapid biosynthesis of several allelochemicals such as monoterpenes, resin acids, and phenolics in addition to wound compartmentalisation (Huber et al. 2004). Our understanding of plant-insect interactions continues to advance rapidly as novel tools at the suborganismal level add to our understanding of mechanisms of both induction of plant defence and detoxification of plant compounds by the herbivores (Bohlmann et al. 2000; Franceschi et al. 2005).

Second, it is now known that pheromones mediate interactions between beetles and the host trees as colonisation is occurring (Borden 1989). Aggregation pheromones are especially critical to host-procurement for "aggressive" species of bark beetles (discussed below). Pheromones serve a diversity of functions, such as attracting conspecifics via short-range and long-range chemical cues. Pheromones may also signal prey availability to "eavesdropping" natural enemies (kairomones), indicate habitat occupancy to interspecific competitors (allomones), and deflect conspecifics into proximal, non-colonised host material through anti-aggregation pheromones (Borden 1989; Raffa 2001). Moreover, many pheromones are synergised by host compounds (Erbilgin et al. 2007). 
Third, we are gaining an ever-deeper understanding of the roles of microbes and associated organisms in the colonisation of host trees by bark beetles (Six 2013). In Swaine's book, fungi were relegated to saprophobes that destroyed the bark when conditions were too wet, rendering it unsuitable for food. Some fungi, particularly those associated with ambrosia beetles, were thought to provide nutrition (ambrosia beetles were not discussed further, as these insects were deemed not "true bark beetles", as some, living outside of trees, were known to "cut their tunnels in the staves of wine casks"). Today, beetlevectored fungi are recognised to fulfil diverse roles in the ecology of bark beetles, such as providing nutrition to developing broods, but also competing against pathogenic fungi, detoxifying and disrupting plant defences, detoxifying host compounds, and producing semiochemical compounds with components identical to those found in bark beetle pheromones (Boone et al. 2008; Klepzig et al. 2009; Lieutier et al. 2009; DiGuistini et al. 2011). Bacteria were not mentioned in Swaine's treatise, although we now know that bacteria and fungi have complex relationships and our understandings of them are in their infancy (Cardoza et al. 2006). Similarly, mites (Acari) are now recognised as important vectors of fungi and bacteria, with mutualistic and antagonistic interactions structuring and influencing community and population dynamics (Hofstetter and Moser 2014).

\section{Classifications of bark beetles}

Swaine's early work set the stage by which we now categorise the eruptive behaviour of bark beetles, recognising that there is a continuum of the tendency to attack and kill live and vigorous versus stressed and moribund trees. Swaine termed these behaviours indicative of "primary" versus "secondary" "enemies". The "primary" and "secondary" designations found widespread use in the ecological literature for the next several decades until being replaced with "aggressive" and "nonaggressive". These latter terms avoid unintended connotations regarding sequence of attack, as some less aggressive beetles such as pine engravers Ips pini (Say) may become principal tree-killing agents on occasions when populations are high (Kegley et al. 1997).
Approximately 98\% of bark beetles are "nonaggressive" species that colonise cones, twigs, or branches, or dead or stressed trees (Lindgren and Raffa 2013). Such trees are easier to colonise because they lack the induced defensive response of live hosts, but present a trade-off in increased competition from other saprophages, decreased nutritional value of substrate for developing brood, and are ephemeral in space and time. In contrast, live trees present a nutritionally superior resource, but can mount vigorous physical and chemical defensive responses to attacking beetles (Raffa and Berryman 1983). Several "aggressive" species of bark beetles thus use aggregation pheromones to attract large numbers of conspecifics to the host and collectively overwhelm host defences. Outbreaks of tree-killing bark beetles can continue for years, unabated, until either the host supply is exhausted or environmental conditions return insect populations to an endemic state (Raffa et al. 2008).

Swaine did describe a third category of bark beetles. "Neutral" species putatively bred only in dying bark and were not known to cause any injury to living trees. Most of these species were found in hardwoods, such as the elm bark beetle, Hylurgopinus rufipes (Eichhoff). We are not aware of any "neutral" classifications applied to bark beetles after the publication of Swaine's work, as most "neutral" bark beetle species would seem to share colonisation traits with non-aggressive species.

Swaine appeared well aware of the current limitations of bark beetle taxonomy at the time of his work. A.D. Hopkins, considered the father of forest entomology in North America, had completed an extensive study of world species (Hopkins 1909a) that Swaine deemed "an exceedingly valuable contribution". Swaine was reluctant, however, to agree with the new terminology of "Scolytidae", relegating it instead to subfamily "Scolytinae" and retaining a more acceptable family name "Ipidae". Disagreements about the status of Scolytidae as a family within Order Coleoptera are still prevalent today (e.g., Bright 2014). Swaine submitted that a final acceptable arrangement of the Ipidae could be made only after a more complete study of world species in the future. Indeed, Swaine lamented the "dearth of biological papers on North American bark beetles", submitting that "time spent upon 
even the species of apparently minor economic importance may give decidedly practical results". Swaine cited four genera of "secondary" bark beetles, for example, as being beneficial to trees by acting to kill lower branches such that "cleaner trunks, and thus better logs" could be produced (genera Polygraphus Erichson, Eccoptogaster Herbst, Pityogenes Bedel, and Pityophthorus Eichhoff; Swaine 1918).

Swaine correctly surmised that most of our understanding of taxonomic breadth of bark beetles would come from the non-aggressive species, as aggressive species were becoming well known. As could be expected, there was a heavy bias on the "primary enemies" as they attacked "perfectly sound trees" causing the "chief" or "primary" injury. In total, Swaine described exactly 100 species of bark beetles in the classification section of his book (Swaine 1918). By 1976, when Bright published "The bark beetles of Canada and Alaska", the list had grown to 214 species of Scolytinae (Bright 1976). Even in doubling the list, however, Bright praised Swaine's effort as "one of the finest works available on the bark beetles of North America".

\section{Factors mediating bark beetle population dynamics}

While mortality to trees could be profound in the early 20th century, elucidating the factors affecting the rise and fall of bark beetle populations was still in its infancy. Swaine postulated that the moisture content of the air in the ovipositional tunnels, temperature of the air and bark, and sunlight were the three most important factors affecting the population dynamics of bark beetles (Swaine 1918; Anderson 1948). The prevailing dogma held that bark beetle populations were simply favoured in conditions that were qualitatively described as warm and moderately dry, and not too wet or cold. These understandings were not developed so much from studies of stand resistance or tree growth rates but rather detailed studies of developing broods of bark beetles in bark sandwich assays. It was thought, for example, that beetles would work to plug excess ventilation holes quickly to preserve humidity levels in the ovipositional galleries. Sunlight warmed the brood environment, but could also be detrimental if desiccation of the bark occurred (Swaine 1918).
Although many early ideas of conditions that fostered beetle success focussed on subcortical environs within a tree, attention broadened to focus on stand conditions in the ensuing decades. This switch was likely precipitated in part by the association of bark beetle outbreaks with periods of drought as longer time series of data on outbreaks became available (Blackman 1931; Beal 1943). Diminished growth rates were considered to be a simple metric of moisture stress, decreasing vigour, and/or increased risk of bark beetle outbreaks (Hopping and Mathers 1945; Hopping and Beal 1948; Safranyik et al. 1975). By the middle of the 20th century, foresters had noted that sufficient soil moisture permitted conifers to drown attacking beetles with excessive resin flow (Prebble 1951).

While the frameworks for population dynamics involving "density-dependent" and "densityindependent" factors had not yet been formally developed by Andrewartha and Birch (1954) and Nicholson (1954), Swaine took pains to make clear that regardless of conditions all increases of bark beetles took place against a template of host availability. Other potentially density-dependent natural controls, such as parasitoids, mites, birds, and fungi received mention in his text, but were dismissed as of minor importance, or restricted to regulating populations of non-aggressive species. While we continue to recognise the importance of availability of breeding substrate as a fundamental density-dependent factor regulating bark beetle population dynamics (Prebble 1951; Økland and Bjørnstad 2006; MacQuarrie and Cooke 2011), the definition of what constitutes a suitable host has changed substantially over the past century.

Swaine suggested that "all our bark beetles have, normally, a preference for dying bark". Hence, any condition that presented an abundance of dying bark was a recipe for increasing bark beetle populations. Critical problem areas included logging operations, settlers' clearings, and cuttings for firewood and trail-making. Swaine declared injured and "slightly burned" trees to be particularly dangerous sources of beetles, although "those [trees] thoroughly charred from base to top may be disregarded". Logically then, Swaine declared that the key principal of control was to reduce the amount of suitable breeding substrate to "the normal amount of dying bark to be found in the woods [sufficing] for 
breeding purposes". Burning of slash after logging operations was crucial, although acceptable clean-up could also be accomplished by sawing or debarking and burning of the wood and bark in winter, and/or occasionally creating and destroying trap trees. Combinations of methods could be used to ensure completion during the late fall, winter, and early spring before emergence of adults in later spring and summer. Whether contending with "windfalls, snow-breaks, [or] flood injuries", the singular goal was simply to "have the dying timber utilized or destroyed before it can give forth its crop of destructive beetles" (Swaine 1918).

In his writings on feeding preferences, Swaine proposed an early formulation of a principal that would later become synonymous with the name A.D. Hopkins. It was obvious from discussion of the suitability of family names of Ipidae versus Scolytidae that Swaine was aware of and had deep appreciation for the work of Hopkins (1909a). Hopkins' host selection principal states that adult insects will breed in host species from which they themselves originated as larvae (Hopkins 1916; Barron 2001). Swaine invoked a less stringent framework - devoid of host species preference but agreed that adult behaviour may mirror prior larval experience in describing the formation of outbreaks. While Swaine stated that all bark beetles were predisposed to dying bark, he asserted that "once they taste green timber they will return to it... Broods of our most injurious species which have bred in an epidemic outbreak in green trees have apparently a decided tendency towards green timber". As we have come to recognise more recently, eruptions among aggressive species of bark beetles dominated by positive feedbacks (Raffa et al. 2008) are associated with densitydependent shifts in host selection from moribund to healthy trees (Raffa et al. 2008; Boone et al. 2011).

Given this behaviour, Swaine thus offered some rules of thumb for management, such as a requirement to remove "three-quarters of greenattacked trees over a winter, with mop up the following year" as such situations occurred. Some 10 years after publication of his textbook, in fact, Swaine declared such methods so reliable in halting populations of mountain pine beetle transitioning to the outbreak stage that "we may confidently look forward to the time when these destructive outbreaks will be prevented throughout the commercial lodgepole pine (Pinus contorta Douglas ex Loudon; Pinaceae) areas of British Columbia and Alberta" (Swaine 1929). Although Swaine underestimated the resiliency of native pine ecosystems, more nuanced, quantitative population-based frameworks for management of species such as the mountain pine beetle can, when executed properly, yield effective results (Carroll et al. 2006; Fettig et al. 2007).

Our understanding of factors that influence changes in bark beetle abundance through space and time has developed considerably from the uniform qualitative descriptions that Swaine provided. Similarly, our understanding of life histories has grown considerably. Swaine postulated that broods of the "Ipidae" (i.e., bark beetles) could develop at different rates at different altitudes and latitudes, asserting that a species of bark beetle that is "single-brooded" in northern Canada may have two broods per year in the middle or southern United States of America. We now recognise this supposition as an early formulation of Hopkins' bioclimatic law that was being developed at approximately the same time at the Agricultural Experiment Station in West Virginia, United States of America (Hopkins 1920, 1938). In the ensuing 100 years, we have developed a much greater appreciation of how temperature can affect shifts in insect voltinism, from altering developmental thresholds to identifying stages of obligate diapause during insect development (Bentz et al. 1991; Bale et al. 2002). Temperature-induced shifts in voltinism can be very important to population dynamics of tree-killing Dendroctonus bark beetles (Hansen and Bentz 2003), but detailed studies on their mechanisms are still not complete (Powell et al. 2000; McKee. 2015).

\section{Tree-killing Dendroctonus species}

Here, we describe the life histories and population dynamics of four species of tree-killing Dendroctonus bark beetles found in Canada. A century ago, Swaine singled out the spruce beetle $D$. rufipennis as responsible for killing "enormous quantities of spruce" on the eastern seaboard, particularly in Maine and south western New Brunswick (Swaine 1918). This insect is an aggressive species: its population dynamics are dominated by positive feedback when at outbreak 
levels, enabling it to exert biome-level influences that can last more than a decade (Berg et al. 2006; Raffa et al. 2008). In contrast, eruptions of the Douglas-fir beetle, D. pseudotsugae, do not typically last more than two to four years as increasing stand resistance limits tree-killing activity as the least vigorous trees are culled from the population (Schmitz and Gibson 1996; Garrison-Johnston et al. 2003). The eastern larch beetle $D$. simplex exhibits similar behaviour, killing trees stressed by predisposing factors, although recent outbreaks may be cause for rethinking this classification (Werner 1986; Langor and Raske 1989a). The mountain pine beetle, $D$. ponderosae, may remain Canada's most famous bark beetle (Safranyik and Carroll 2006), given the scope of past and current outbreaks (Campbell et al. 2007).

Each of the sections on spruce beetle, Douglas-fir beetle, and eastern larch beetle are organised around general life histories and factors that affect transitions from endemic to incipient to epidemic levels (Safranyik and Carroll 2006; Weed et al. 2015), as well as notes on management where applicable. The section on mountain pine beetle is considerably shorter, given recent work that captures its natural history, ecology, and population dynamics in depth (e.g., Safranyik and Carroll 2006; Six and Bracewell 2015). Due to nuances in their individual and population behaviour, regulating factors that may be more important in one species may not be fully addressed in another. A short section on pressing topics for future research in population dynamics concludes each species-specific section. Finally, a concluding section discusses emerging problems for the decades ahead. These topics include aspects of global change such as invasive species, climate change, and ongoing range expansion exhibited by the mountain pine beetle.

\section{The spruce beetle, Dendroctonus rufipennis}

Transcontinental within the spruce forests of Canada, the spruce beetle, D. rufipennis Kirby, infests all species of spruce, although white spruce (Picea glauca (Moench) Voss; Pinaceae), Sitka spruce ( $P$. sitchensis (Bongard) Carrière), Engelmann spruce $(P$. engelmannii Parry ex Engelmann), and Lutz spruce (Picea $\times$ lutzii Little) are the most economically important trees.
Swaine described several putative beetle species from different species of spruce, but simultaneously postulated that $D$. borealis, D. obesus, $D$. engelmanni, and D. piceaperda were one species. Dendroctonus rufipennis may have been omitted from that group because it was erroneously reported in white pine (Pinus strobus Linnaeus; Pinaceae) and jack pines (Pinus banksiana Lambert) (Swaine 1918). Wood (1969) synonymised $D$. borealis, D. engelmanni, D. obesus, $D$. piceaperda, and $D$. similis with $D$. rufipennis. Adult spruce beetles are $\sim 6 \mathrm{~mm}$ long by $3 \mathrm{~mm}$ wide, dark brown with rufous or black elytra (Massey and Wygant 1954; Holsten et al. 1999).

Spruce beetles typically initiate attacks from late May to early June (Safranyik 2011). Females are the host selecting sex, and produce seudenol (Vite et al. 1972), frontalin (Gries et al. 1988), verbenene (Gries et al. 1992), and 1-methyl-2cyclohexen-1-ol (MCOL) (Borden et al. 1996). Frontalin is attractive to both sexes (Furniss et al. 1976). Spruce beetles also produce an antiaggregation pheromone $\mathrm{MCH}$, which repels attacking beetles (Furniss et al. 1976). Upon entering the tree, the first $2-3 \mathrm{~cm}$ of the egg galleries are constructed on a slight diagonal to the grain (Safranyik et al. 1983; Safranyik and Linton 1999). After mating, females extend the galleries an average length of $13 \mathrm{~cm}$ in live trees (Safranyik et al. 1983). Eggs are laid in groups along the length of both sides of the egg gallery; however, the original $2-3 \mathrm{~cm}$ is left free from eggs (Safranyik and Linton 1999). On average, eight eggs are laid per $\mathrm{cm}$ of gallery in live trees (Massey and Wygant 1954; Safranyik and Linton 1999). In felled trees, an average of 8.5-9.7 eggs is laid per $2.5 \mathrm{~cm}$ (Knight 1961). Larvae bore horizontally from the egg gallery in groups for the first two instars, after which they form individual mines that can intersect.

The larvae pass through four larval instars. The late fourth instar or pre-pupa is typically the overwintering stage within the host tree, depending on weather conditions (Dyer and Hall 1977). Once temperatures begin to increase in the spring, larval development continues until late in the summer when pupation occurs. A portion of the adult beetles in standing trees emerge in late August and then travel down the base of the tree to bore in again and overwinter (Massey and Wygant 1954; Safranyik and Linton 1999; British Columbia 
Ministry of Forests and Range 2012). Knight (1961) estimated that $3-88 \%$ of adult beetles emerged from standing trees to bore into the base of the tree for overwintering, although adult beetles in wind-thrown or slash trees tend to overwinter without emerging and repositioning themselves (Dyer and Taylor 1971; McCambridge and Knight 1972; Schmid and Frye 1977). Adults exhibit what is thought to be an obligate overwintering reproductive diapause before achieving sexual maturity and attacking new trees (Hansen et al. 2001).

Spruce beetles are associated with a multitude of microorganisms. Leptographium abietinum (Peck) Wingfield (Ophiostomataceae) is the most common fungal associate (Davidson 1955; Ohsawa et al. 2000; Six and Bentz 2003; Aukema et al. 2005). Differences in fungal composition may occur between geographic areas, however, as well as between hosts (i.e., live trees, stumps, deadfall) and population phases (Aukema et al. 2005). Cardoza et al. (2006) found four major fungi on spruce beetles from the Kenai Peninsula in Alaska, United States of America: L. abietinum; Aspergillus fumigatus Fresenius (Trichocomaceae,); A. nominus Kurtzman, Horn, and Hesseltine; and Trichoderma harzianum Rifai (Hypocreaceae). The latter three species decrease brood survival, although adult beetles exude oral secretions containing bacteria that inhibit the growth of some of the pathogenic species (Cardoza et al. 2006).

Dendroctonus rufipennis primarily attacks downed trees (Safranyik and Linton 1999; Safranyik 2011; British Columbia Ministry of Forests and Range 2012), as live trees present a multitude of defences that a beetle must overcome or avoid. When spruce beetles attack a Sitka or Lutz spruce, for example, the tree produces resin and periderm to exclude the beetles from furthering the attack. If beetles and associated fungi successfully breach the first line of defence, the production of antimicrobial stilbenes and monoterpenes is increased (Werner and Illman 1994). When a tree is stressed (e.g., excessive heat, water excess/deficit, injury, etc.), defensive capacity is reduced. Drought stress, for example, may reduce host tree vigour by affecting water absorption, photosynthesis, and other physiological processes (Kozlowski 1982).

Although trees low in vigour may be easier to colonise, there is a trade-off between host quality and host defence with which all species of bark beetles must contend. Stressed trees present lower quality resources for bark beetles. Spruce beetles from poor quality hosts exhibit slower boring rates, slower yolk deposition rates, lower egg production per unit of gallery length, increased egg-free gallery length, and reduced numbers of galleries (Sahota and Thomson 1979; Thomson and Sahota 1981). Fitness, judged by the reproductive success of an individual, is lower in poor quality spruce beetle populations (Sahota and Ibaraki 1979). Poor quality beetles are less able to contend with intraspecific and interspecific competition (Sahota and Thomson 1979).

Competitive vigour is critical for spruce beetle because competition from other bark beetles is a major limiting factor for endemic populations of $D$. rufipennis, especially where there is an abundance of downed woody debris (Table 1). Consequences of intraspecific and interspecific competition include reduced reproductive success, reduced beetle vigour (i.e., smaller offspring), and increased mortality (Safranyik and Linton 1985; Sahota et al. 1987). Ips perturbatus (Eichhoff), for example, is a potential competitor of D. rufipennis that also preferentially attacks recently downed trees or trees affected by stress (e.g., drought or fungi) (Holsten et al. 1999). Its primary host is Picea Dietrich, but also occurs on Pinus banksiana Lambert and $P$. contorta (Bright 1976). Ips perturbatus is univoltine throughout Alaska (Holsten et al. 1999) and Alberta, Canada (Robertson 2000). Other important competitors with spruce beetle include Dryocoetes affaber (Mannerheim) in western North America (Gara et al. 1995), I. tridens in British Columbia (Poland and Borden 1997), and P. rufipennis in the Great Lakes region (Haberkern and Raffa 2003).

In situations where beetle densities exceed the carrying capacity of the woody debris present (Garbutt et al. 2006), beetles will begin to attack live trees (Table 1). This behaviour marks the beginning of the incipient-epidemic population phase. Once beetles reach the epidemic phase, host plant defences no longer constrain beetle population growth (Wallin and Raffa 2004; Raffa et al. 2008; Boone et al. 2011). Over the past 25 years, for example, the spruce beetle has erupted across vast areas of Alaska, United States of America and the adjacent Yukon Territory of Canada (Berg et al. 2006; Raffa et al. 2008). 
Table 1. Summary of predominant positive and negative feedback processes impacting population dynamics of the spruce beetle, Douglas-fir beetle, eastern larch beetle, and mountain pine beetle.

Population phase

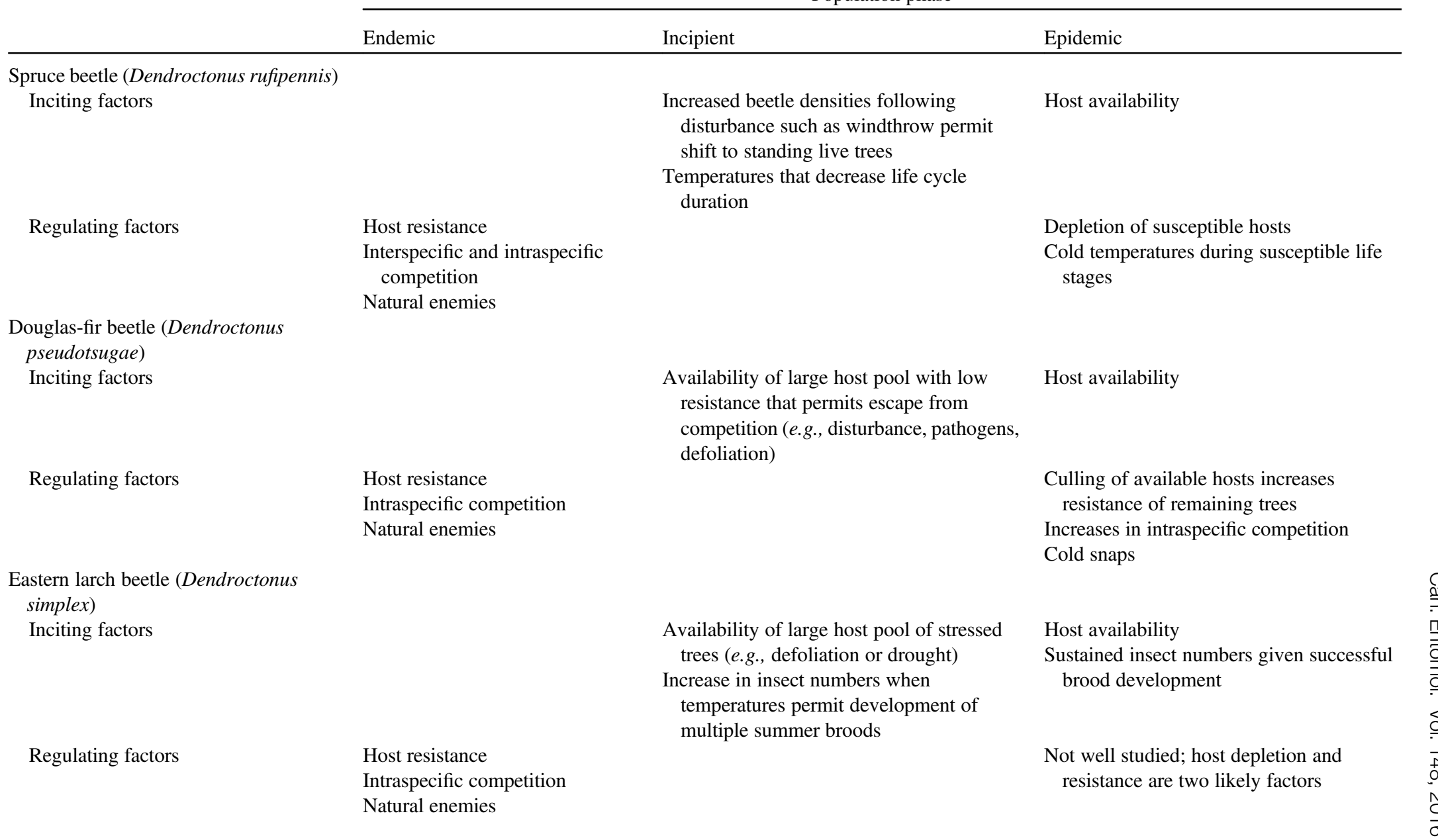


The epidemic phase has been characterised as a minimum of two clumps of five standing infested trees per 5 acres ( 2 ha) area (Bentz and Munson 2000). A tree with a diameter at breast height $(\mathrm{DBH})$ of 20 inches $(51 \mathrm{~cm})$ may be infested to a height of 35 feet (11 m) (Knight 1960). Spruce beetles may also attack stumps below the duff line (Safranyik and Linton 1999). Signs of attack may not be seen until the following year or two after attack, when the needles turn greenish-yellow and fall off the tree. On some trees, the only evidence of attack may be red boring dust at the base of the tree instead of pitch tubes (Massey and Wygant 1954). Spruce beetles often initiate their gallery entrance under a bark flake, making it challenging to see evidence of colonisation.

Spruce beetles attack large-diameter trees during outbreaks, but tree growth rate is a better predictor of beetle success than diameter alone. Trees that were fast growing but had smaller diameters can be more successful at repelling beetle attack versus larger diameter trees that may be growing more slowly (Hard et al. 1983). Reductions in radial growth may be a proxy for tree stress, indicating allocation of limited energy reserves to shoot, root, and cone growth at the expense of stemwood production (Waring and Pitman 1980). Spruce beetles do prefer to attack trees when radial growth is slowed: during warm, dry weather or before the soil thaws in the spring. Heavily attacked trees experience slower radial growth before beetle attack relative to unattacked trees (Hard 1987).

The greatest advance in our understanding of spruce beetle population dynamics since the time of Swaine has been the elucidation of some of the mechanisms by which beetle populations transition from endemic to eruptive population phases (Table 1). Temperature can be critical to this population phase transition in which the insects increase in abundance, escaping competitive pressure, and transitioning to successful mass attacks on live trees. Temperature has long been known to mediate development rates. Spruce beetles exhibit a larval development threshold of $6.1^{\circ} \mathrm{C}$ and optimal fecundity and development rates at $21.1^{\circ} \mathrm{C}$ (Dyer and Hall 1977; Sahota and Thomson 1979). Spruce beetles exhibit a facultative pre-pupal diapause and what is thought to be an obligate adult diapause. When pre-pupae experience threshold cool temperatures 
of appropriate duration, a facultative diapause arrests development until the following season. If favourably warm environmental temperatures prevail, then spruce beetles proceed to the adult overwintering diapause stage uninterrupted (Hansen et al. 2001, 2011). As such, increases in mean annual temperatures and heat accumulation have, in certain areas, allowed the spruce beetle to shift voltinism from the typical two-year or even three-year cycles (Dyer 1969; Massey and Wygant 1954; Safranyik et al. 1983; Safranyik and Linton 1999; Safranyik 2011) to one-year life cycles. This shift has resulted in elevated rates of population increase and contributed to recent large-scale outbreaks of the beetle (e.g., Alaska and the western United States of America).

Similar to behaviour exhibited by other aggressive Dendroctonus species such as mountain pine beetle, outbreaks will continue unabated until the host supply is diminished or environmental conditions return the beetle populations to an endemic state (Table 1). In late epidemic phases, for example, non-host trees (e.g., Pinus Linnaeus) may occasionally be attacked, but broods usually do not mature (Massey and Wygant 1954; McCambridge and Knight 1972; Safranyik et al. 1983). The occurrence of low temperatures before beetles become cold hardy can also cause populations to collapse, although there appears to be both geographic and temporal variation in this trait. Temperatures of only $-15^{\circ} \mathrm{C}$ and $-30{ }^{\circ} \mathrm{C}$ have killed most adults and larvae, respectively, in Colorado, United States of America (Massey and Wygant 1954). Beetles exhibit supercooling points of $-12^{\circ} \mathrm{C}$ in the summer and $-31{ }^{\circ} \mathrm{C}$ in the winter in Alaska (Miller et al. 1987), although a more recent study in Nova Scotia described supercooling points of $-44^{\circ} \mathrm{C}$ (Rousseau et al. 2012).

Natural enemies may impact spruce beetle populations, although their effect is negligible in outbreak conditions. Spruce beetles have a diverse suite of natural enemies in western North America (Massey and Wygant 1954; McCambridge and Knight 1972; Miller et al. 1987; Gara et al. 1995). Woodpeckers (Piciformes: Picidae) such as the alpine three-toed woodpecker, Picoides dorsalis dorsalis (Baird); Rocky Mountain hairy woodpecker, Picoides villosus monticola (Anthony); and the downy woodpecker, Picoides pubescens (Linnaeus) have been known to destroy as much as $75 \%$ of beetle populations in Colorado (Massey and Wygant 1954). Thanasimus undatulus Say (Coleoptera: Cleridae) is a primary predator of the spruce beetle in western North America, although it also responds to pheromones of Ips tridens Mannerheim (Poland and Borden 1997). Ips species naturally displace the spruce beetle through competition (McCambridge and Knight 1972) and T. undatulus will preferentially feed on I. tridens, therefore potentially reducing the impacts of interspecific competition on the spruce beetle.

Management of eruptive bark beetles such as the spruce beetle thus take one of two forms: (i) indirect or proactive tactics intended to limit the amount of susceptible host material and reduce the probability of rapid population increases; or (ii) direct or reactive tactics intended to destroy infested material and directly reduce beetle populations (Prebble 1955; Carroll et al. 2006). Indirect tactics in intact stands comprise any activity that will improve tree vigour (e.g., thinning) and thereby increase the resistance of high value, highly susceptible spruce stands (Holsten et al. 1999). Indirect approaches are also applicable to disturbed stands. During harvesting, keeping stumps low $(<45 \mathrm{~cm}$ high), and limiting the quantity of large-diameter cull logs and slash will reduce the likelihood of local population increases (Holsten et al. 1999). For accessible sites with downed trees due to wind or other disturbance, prompt removal of $\operatorname{logs}$ (before infestation) can also limit the build-up of populations. Given that most spruce beetle epidemics are linked to extensive windthrow events (Humphreys and Safranyik 1993; Holsten et al. 1999) or other widespread forest stressors such as drought (Sherriff et al. 2011), however, the highly intensive nature of indirect tactics can preclude their general application.

Consequently, direct control tactics are often the primary means of limiting spruce beetle impacts. Sanitation harvesting of infested logs and trees is the most common direct control tactic (Humphreys and Safranyik 1993). Where infestations are accessible to conventional harvesting operations, infested logs/trees can be removed and transported to a mill where prompt processing will cause the mortality of progeny. Infested trees in inaccessible areas can be felled, bucked, piled, and burned to kill broods. Sanitation harvesting can be augmented by tactics that help concentrate 
beetle populations. Since spruce beetles will readily infest logs, trap trees (i.e., large diameter $(>30 \mathrm{~cm})$, felled trees) can be used to attract up to $10 \times$ the number of foraging beetles compared to an intact standing tree (Holsten et al. 1999). Trap trees can be further augmented using semiochemicals. Aggregation pheromones can potentially attract large numbers of beetles. Aggregation pheromones can be deployed alone or in combination with anti-aggregation pheromones to protect high value trees and stands in a "push-pull" manipulation (sensu Borden et al. 2006), although there may be regional variation in effective pheromone blends.

The juxtaposition between large outbreaks in the continental east a century ago (Swaine 1918; Prebble 1951) versus Alaska and the Yukon in recent decades (Berg et al. 2006; Raffa et al. 2008) reminds us that many puzzles await solutions concerning the population dynamics of spruce beetles. Spruce beetles are still present but no longer exhibit landscape-level eruptions in the forests of eastern North America, which may be due to changes in forest structure over the past century. It is difficult to untangle long-term changes in forest composition from confounding changes in climate, however. For example, long-term drought stress from lengthened growing seasons devoid of concomitant increases in precipitation in Alaska has reduced the growth rates and vigour of spruce trees (Barber et al. 2000), increasing the availability of susceptible hosts (Berg et al. 2006). El Niño years, for example, coupled with late summer drought are positively correlated with the occurrence of spruce beetle outbreaks (Sherriff et al. 2011). Yet climatic changes that potentially yield aboveaverage levels of precipitation could also alter this system. An increase in precipitation as snow in the northern parts of the range of the spruce beetle, for example, predicted under some climate change scenarios (e.g., Intergovernmental Panel on Climate Change 2014), may favour beetle survival because snow can insulate overwintering beetles from lethal minimum temperatures and minimise woodpecker predation (McCambridge and Knight 1972). Similarly, increased snow loading combined with warmer spring temperatures may allow beetles to attack trees before their roots have thawed, thereby improving attack success. The net effect of warmer temperatures and altered precipitation regimes on the spruce beetle may be a greater likelihood of population increases and landscape-scale outbreaks.

\section{The Douglas-fir beetle, Dendroctonus pseudotsugae}

The Douglas-fir beetle preferentially colonises downed and low-vigour Douglas-firs (Pseudotsuga menziesii (Mirbel) Franco; Pinaceae) under endemic conditions (Hopkins 1909b; Lejeune et al. 1961; Furniss and Carolin 1977; Fredricks and Jenkins 1988; Schmitz and Gibson 1996; Powers et al. 1999; Humphreys 2000). It is considered the primary insect enemy of Douglas-fir (Furniss and Carolin 1977). The beetle will also attack, however, standing western larch (Larix occidentalis Nuttall; Pinaceae). Logs of western hemlock (Tsuga heterophylla (Rafinesque) Sargent; Pinaceae), western redcedar (Thuja plicata Donn ex Don; Pinaceae), and Brewer spruce (Picea breweriana Watson; Pinaceae) are occasionally colonised. Douglas-fir, however, represents the only potential host species that can be successfully colonised by the beetle when alive (Furniss 1976).

Mature Douglas-fir beetles emerge, disperse and colonise new host material in early spring. Mated females may re-emerge during the early summer and establish a second "sibling" or "sister" brood in additional host material. Sister broods are established by the same parent beetles as the first brood, but are sometimes referred to as a second or partial "generation" (Hopkins 1909b; Wood 1982; Lessard and Schmid 1990; Schmitz and Gibson 1996). Approximately $20 \%$ of female beetles are reported to re-emerge in order to lay a second brood (Schmitz and Gibson 1996). Callow adults of the first brood are normally present in host trees by early August but remain under the bark to sclerotise and overwinter. Sister broods overwinter as late instars and complete development the following spring. By early summer, the sister brood completes development, emerges, and colonises host material. This timing of emergence corresponds with the re-emergence of spring-attacking females and thus, a second set of host material may be colonised cooperatively by re-emergent and newly emergent adult beetles (Hopkins 1909b; Furniss 1976; Wood 1982; Humphreys 2000). 
Similar to the spruce beetle, the Douglas-fir beetle thrives in physiologically compromised host material with reduced capacities for an oleoresin defensive response (Rudinsky 1966) and diminished carbohydrate reserves for monoterpene production (Webb and Karchesy 1977). At endemic levels, the beetle prefers to infest the stumps, fallen branches, wind-thrown stems, and logging slash of Douglas-fir as well as low-vigour standing trees that have been severely injured by wind or snow breakage, fire, lightening, root disease, drought, and defoliation (Table 1; Hopkins 1909b; Lejeune et al. 1961; Furniss and Carolin 1977; Fredricks and Jenkins 1988; Schmitz and Gibson 1996; Powers et al. 1999; Humphreys 2000). Indeed, the relationship between Douglas-fir infected with various species of root rot fungi (e.g., Armillaria solidipes Peck (Physalacriaceae) and Phellinus weirii (Murrill) Gilbertson (Hymenochaetaceae)) and attack by Douglas-fir beetle is most pronounced during endemic beetle population phases (Furniss et al. 1979, 1981; Humphreys 2000). A similar relationship exists for Douglas-firs that have experienced heavy defoliation by western spruce budworm Choristoneura occidentalis (Freeman) (Lepidoptera: Tortricidae) or the Douglas-fir tussock moth Orgyia pseudotsugae (McDunnough) (Lepidoptera: Lymantriidae) (Wright et al. 1984; Fredricks and Jenkins 1988).

Reduced host vigour allows Douglas-fir beetles to colonise Douglas-fir material at low attack densities of 43-86 attacks $/ \mathrm{m}^{2}$ (4-8 attacks/ $\mathrm{ft}^{2}$ ) and reduce intraspecific competition, increasing reproductive success (Atkins and McMullen 1960; McMullen and Atkins 1961; Schmitz and Rudinsky 1968; Furniss et al. 1981; Wright et al. 1984; Powers et al. 1999). The availability of stressed host material on the landscape is often severely limited, however. Thus, material is often colonised at densities sufficient to promote intraspecific competition and limit beetle reproductive success, constraining population growth (Furniss et al. 1979, 1981). Standing, vigorous trees located near to the attractant source of stressed material are also often attacked, but successful beetle colonisation often fails due to the intact oleoresin defences of the healthy trees. Such trees therefore act as beetle "sinks" and further serve to limit beetle reproductive success and maintain low beetle densities (Johnson and Belluschi 1969; Furniss et al. 1979).
The shift of Douglas-fir beetle populations from endemic to incipient-epidemic phases occurs when an abundance of low-vigour host material fosters conditions for beetle success; that is, large numbers of beetles can colonise at low densities across a broad resource with reduced intraspecific competition (Table 1). The influx of such host material may occur from acute disturbances such as low intensity fires, logging practices creating large amounts of slash, or wind-throw events (Atkins and McMullen 1960; Furniss and Carolin 1977; Powers et al. 1999). The importance of wind-throw for creating suitable breeding material is more prevalent in the coastal and northern Rocky Mountain Douglas-fir forests where trees tend to be larger and more prone to wind-throw relative to the southern Rocky Mountains where trees are smaller and more wind firm (Furniss et al. 1981). Even small areas or "micro-sites" within a larger stand, however, can catalyse beetle activity that will spread to the larger stand (Negrón et al. 2001).

In addition to acute inputs of host material, chronic declines in stand vigour may create favourable conditions for increases in beetle abundance. Older stands of Douglas-fir with declining vigour are also associated with elevated levels of beetle attack, for example (Furniss et al. 1981). High levels of activity may also be noted in stands with a basal areas of Douglas-fir (Furniss et al. 1979; Negrón 1998; Negrón et al. 1999; Powers et al. 1999) greater than surrounding areas (Furniss et al. 1979, 1981; Hadley and Veblen 1993; Negrón 1998). Dense stands may be of lower vigour (Negrón 1998) due to moisture stress (Furniss et al. 1981). Additionally, dense stands provide increased shading that allows the beetles to colonise the entire tree bole because Douglas-fir beetles tend to avoid sunlit aspects of standing or downed host material (Furniss et al. 1981) that desiccate their tunnels (Swaine 1918). At a stand level, trees on southern aspects experience greater seasonal and daily declines in oleoresin exudation pressure than trees growing on northern aspects. Trees growing at lower elevations and on east, south, or southwest aspects also tend to be drier (Powers et al. 1999) and are more often associated with increased beetle activity (Schmitz and Gibson 1996; Powers et al. 1999; Humphreys 2000).

Populations of Douglas-fir beetles in lowvigour material may increase rapidly (Atkins and 
McMullen 1960; McMullen and Atkins 1961; Schmitz and Rudinsky 1968; Furniss et al. 1981; Wright et al. 1984; Powers et al. 1999); even $>10$-fold over a single generation (Atkins and McMullen 1960). In fact, outbreaks can be initiated after just two generations of beetles reproducing in large volumes of wind-thrown timber (Wright et al. 1984). Increasing Douglas-fir beetle populations rapidly exploit all available vigourimpaired host material leading to an increased frequency of attacks on standing trees that may be of reduced health and vigour but still possess intact resin defence systems (Johnson and Belluschi 1969; Furniss et al. 1981; Humphreys 2000). However, defences of weakened trees are quickly overwhelmed by the sheer number of attacking beetles, with the result being the death of some proportion of the standing timber (Johnson and Belluschi 1969; Furniss et al. 1979; Powers et al. 1999). The most vigorous trees have a greater threshold for repelling beetle attacks before tree mortality occurs (Furniss et al. 1979).

Douglas-fir trees that tend to be killed early during the incipient-epidemic population phase of Douglas-fir beetle outbreaks are generally large $(20+\mathrm{cm}$ diameter at breast height), mature $(120+$ years old), exhibit thick bark and phloem, demonstrate low growth rates during the previous 5-10 years, and have compromised oleoresin defence capabilities (Rudinsky 1966; Furniss et al. 1979, 1981; Lessard and Schmid 1990; Powers et al. 1999; Shore et al. 1999; Humphreys 2000; Garrison-Johnston et al. 2003). Brood production in larger diameter trees is enhanced compared to low diameter trees, however, and supports the transition of the beetle population to the epidemic phase (Humphreys 2000).

During the epidemic population phase, larger areas of standing timber are successfully attacked, colonised, and killed by the Douglas-fir beetle (Table 1). The large numbers of beetles present within a stand are generally able to attack and overcome the defences of even the most vigorous trees. Accordingly, no relationship exists between tree vigour and the ability to survive beetle attacks during the epidemic phase (Powers et al. 1999; Garrison-Johnston et al. 2003). Hence, larger areas of the surrounding stand or forest are affected by beetle attack and Douglas-fir mortality. Mortality across thousands of hectares of Douglas-fir forest is not uncommon during outbreaks (Schmitz and Gibson 1996). It is estimated that on an annual basis, the Douglas-fir beetle is responsible for killing hundreds of millions of board feet of timber throughout the range of Douglas-fir (Furniss and Carolin 1977; Wood 1982). Outbreaks of the Douglas-fir beetle in standing timber typically last from two to four years, but may last longer in some instances (Furniss et al. 1979; Schmitz and Gibson 1996).

The decline of Douglas-fir beetle populations from epidemic back to endemic levels is tightly linked to a coincident density-dependent decline in suitable host material (i.e., a relative increase in stand resistance), increases in intraspecific competition among Douglas-fir beetle larvae within successfully killed hosts, and subsequent declines in beetle reproductive success and offspring production (Table 1; Atkins and McMullen 1960; McMullen and Atkins 1961; Johnson and Belluschi 1969; Furniss et al. 1979; Wright et al. 1984; Powers et al. 1999; Garrison-Johnston et al. 2003). With each successive year of beetle attack, the most susceptible trees are removed from the population such that the most vulnerable trees in a stand are usually depleted within three years (Garrison-Johnston et al. 2003). This cull results in a significant increase in the relative resistance to beetle attack among the remaining trees with each year of tree mortality (Furniss et al. 1979). The increased level of resistance among remaining trees translates into higher thresholds of beetle attack required to overcome host defences (Johnson and Belluschi 1969). The increased beetle attack densities needed to colonise such trees creates increased intraspecific competition among developing larvae that is detrimental to brood production (McMullen and Atkins 1961; Schmitz and Rudinsky 1968; Powers et al. 1999). As a result of such competition (i.e., $161-183 / \mathrm{m}^{2}\left(15-17\right.$ attacks $\left./ \mathrm{ft}^{2}\right)$; Atkins and McMullen 1960), many vigorous trees killed by attacking beetles serve as beetle sinks rather than beetle sources, slowing population growth (Johnson and Belluschi 1969; Furniss et al. 1979, 1981). Under such conditions, Furniss et al. (1979) found that $55 \%$ of standing Douglas-fir trees that were attacked and killed by Douglas-fir beetles exhibited brood production that was either below or at parity with the number of attacking beetles needed to kill the tree. 
Natural enemies known to prey on Douglas-fir beetles include Enoclerus sphegeus (Fabricius) (Coleoptera: Cleridae), Thanasimus undatulus (Say) (Coleoptera: Cleridae), Temnoscheila chlorodia (Mannerheim) (Coleoptera: Trogossitidae), Coeloides brunneri Viereck (Hymenoptera: Braconidae), and Medetera aldrichii Wheeler (Diptera: Dolichopodidae) (Furniss and Carolin 1977). None of these insects have been found to be important regulatory agents during Douglas-fir beetle outbreaks, however (Furniss et al. 1979). As with other Dendroctonus species, natural enemies may only impact populations of Douglasfir beetles at small scales when beetle populations are at low densities (Powers et al. 1999).

Efforts to manage the Douglas-fir beetle typically focus on indirect tactics to limit the rapid increase of populations. Experimental thinning of overly dense Douglas-fir stands has been shown to substantially reduce Douglas-fir beetle infestation by increasing tree vigour, reducing stem shading, and limiting the availability of low-vigour host material such as wind-throw, breakage, and suppressed trees (Williamson and Price 1971). It is important, however, that thinning operations avoid collateral damage to remaining standing trees. The amount of slash left within the stand must also be carefully managed following harvesting operations (Swaine 1918). The reported preference of Douglas-fir beetles for logging slash is such that beetles avoid attacking standing timber so long as a sufficient supply of slash is available. Thus, it has been recommended to balance the availability of logging slash so that enough is available to prevent beetles from attacking standing timber while disallowing beetle populations to increase dramatically (Lejeune et al. 1961). Similar to the spruce beetle, sanitation harvesting together with the use of trap trees and semiochemical manipulation are common direct control tactics applied to reduce Douglas-fir beetle populations (Humphreys 2000; Laidlaw et al. 2003; Ross and Wallin 2008; Gillette et al. 2009).

As with spruce beetle, variations in weather and climate can impact changes in abundance in space and time for Douglas-fir beetles. Swaine's qualitative association of moderately warm weather with increased populations of bark beetles would seem to hold true for Douglas-fir beetle. Early, warm spring weather, for example, may stimulate the beetles to emerge quickly and synchronously.
However, if cool, wet weather sets in shortly thereafter, the emergent beetles are left unable to attack host trees. Exposed to the elements, beetles may be unable to tunnel into host bark for protection and thus succumb to predation and exposure (Atkins and McMullen 1960). Summer temperatures, which dictate the rate of larval development, can reduce the potential for the development of population outbreaks if too cool (Johnson and Belluschi 1969). During the fall, sudden cold snaps can cause $60-80 \%$ mortality to the overwintering beetle population (Atkins and McMullen 1960). Such temperatures can exert different rates of mortality to the different overwintering life-stages (Johnson and Belluschi 1969).

There are several aspects of the lifecycle and reproductive biology of the Douglas-fir beetle that have not been well studied to date, despite the ease with which it can be captured in traps for experimental purposes. The beetle is reported to exhibit a univoltine life cycle (Wood 1982; Schmitz and Gibson 1996; Humphreys 2000). This life cycle is putatively enforced by an obligate reproductive diapause of newly developed brood adults (Furniss 1976). This obligatory diapause period has never been empirically characterised, however. The habits of summer-emergent brood adults that overwintered as larvae to engage in host attack without an overwintering period as adults (Hopkins 1909b; Furniss 1976; Schmitz and Gibson 1996; Humphreys 2000) suggests that diapause in this beetle cannot be obligate. Similarly, the impacts of partial or complete sister broods on the population dynamics of this insect are unknown, as is the case for many bark beetles (McMullen and Atkins 1961; Anderbrant 1989; Dworschak et al. 2014; Öhrn et al. 2014). The establishment of second sibling broods by parent beetles has the potential to ameliorate the detrimental effects of intraspecific competition among larvae of the first brood, and could have important ramifications for adult reproductive success and population dynamics (McMullen and Atkins 1961). Microorganisms also mediate reproductive success, although relatively few studies have attempted to characterise microorganisms associated with the Douglas-fir beetle (Lu et al. 1957; Lewinsohn et al. 1994; Solheim and Krokene 1998). Finally, research that investigates how the Douglas-fir beetle may react to future 
climate scenarios would be beneficial. In particular, efforts to understand the effect that changing climatic patterns may have on the vitality of Douglas-fir forests could provide useful insights into the potential tree-killing behaviour of the Douglas-fir beetle in the forthcoming decades.

\section{The eastern larch beetle, Dendroctonus simplex}

The eastern larch beetle has traditionally been considered a nonaggressive bark beetle that colonises eastern larch (tamarack) (Larix laricina (Du Roi) Koch; Pinaceae) (Hopkins 1909b). Eastern larch beetles typically demonstrate a propensity for attacking tamaracks that are weakened, injured, dying, or recently dead (Hopkins 1909b; Wood 1982). Commonly, tamaracks colonised by eastern larch beetles are stressed by a local disturbance event such as wind throw, ice damage, flooding, timber harvest, or old age (Langor and Raske 1988a, 1989a, 1989b). In recent decades, however, the eastern larch beetle has undergone landscape-level outbreaks and has demonstrated that the beetle should potentially be reconsidered as an aggressive species (Werner 1986; Langor and Raske 1989a; McKee 2015). Due to a historic designation as a bark beetle of low economic importance, studies on the natural history and ecology of eastern larch beetles have been extremely limited (Seybold et al. 2002). As such, knowledge of the mechanisms that allow the eastern larch beetle to transition from endemic to epidemic population phases are not well understood. However, historical reports of eastern larch beetle natural history during localised beetle activity as well as more recent research undertaken during landscape-level outbreaks provides some insight to the potential mechanisms that govern the population dynamics of this insect (McKee 2015).

Adult eastern larch beetles generally begin to emerge from natal hosts in mid-May. Emergence generally peaks rapidly, but continues into the first week of June. During very warm springs, emergence may begin the first week of May and be complete by the end of May. Beetle attack on new host trees or downed material occurs within a few days of beetle emergence; however peak attack periods do not always coincide with peak emergence (McKee 2015). Eggs of the first brood are laid within a few days of host material being attacked. Similar to Douglas-fir beetles, adult females will often re-emerge from fully colonised host material to establish a second, and, occasionally, a third sibling brood. Larvae develop quickly, such that adult progeny of the first sibling brood are often present within host material by early July. The presence of adult progeny of the second brood is variable and depends on the year and the timing of brood establishment by the re-emergent adult beetles. Accordingly, adult progeny can first be found in host material ranging from mid-July to mid-September. Development of the third sibling brood to the adult stage is also quite variable and can be as early as late-August of the year of oviposition or as late as early-summer of the year following oviposition (McKee 2015).

Similar to D. rufipennis, brood adults of the eastern larch beetle may reposition themselves within standing natal host trees before winter by emerging from the pupal chamber, descending to the base of the tree, and boring back under the bark to create hibernal galleries in which to overwinter. The pre-winter emergence of adult progeny of the first sibling brood typically begins one to two weeks after development to the brood adult life-stage occurs, but may be up to four weeks later for the brood adults of the second and third sibling broods. In some cases, brood adults of sibling broods do not engage in pre-winter emergence (Hopkins 1909b; Swaine 1911; Simpson 1929; Prebble 1933; Werner 1986; Langor and Raske 1987a, 1987b).

Similar to other bark beetles, and consistent with Swaine's models of bark beetle abundance, the abundance of eastern larch beetles appears to be highly correlated with preferred resource availability (Table 1). Localised disturbance events (e.g., snow breakage, wind-throw) injure single or small groups of tamaracks and create a preferred resource for endemic eastern larch beetles that is limited in quantity, ephemeral, and is spatially separated across the landscape (Hopkins 1909b; Langor and Raske 1988a, 1989a, 1989b). The use of small pockets of stressed tamaracks apparently sustains endemic eastern larch beetle populations and temporarily facilitates a short period of increased beetle activity lasting one to three years. Such increases in abundance remain largely confined to the stressed tamarack resource, however (Langor and 
Raske 1988a). Localised, short-term beetle activity is considered typical for eastern larch beetles and has been reported for over 100 years (Hopkins 1909b). In general, eastern larch beetle populations decline to unnoticeable levels when the supply of stressed tamaracks (or material) has been fully used and the only available resources are standing, healthy trees. The oleoresin defence system of living tamaracks, as well as of recently dead host material, is known to cause mortality among attacking adult beetles as well as developing larvae, but has not been studied in detail (Simpson 1929; Langor and Raske 1988b; Werner 1995).

Disturbance events that act on a broad rather than local scale may compromise the health of tamaracks across larger areas and provide increased amounts of material that are suitable for eastern larch beetle colonisation and reproduction. Widespread defoliation of tamaracks appears to be important for inciting landscape-scale outbreaks of eastern larch beetles, for example (Werner 1986; Langor and Raske 1988a, 1989b), as radial growth of tamarack is significantly reduced by repeated defoliation events (Benoit and Blais 1988; Tailleux and Cloutier 1993). The increase in reproductive output within stressed host trees allows beetle populations to surpass critical population density thresholds. Breaching these thresholds permit beetles to attack, colonise, and successfully reproduce within large expanses of healthy, vigorous larch forests (Langor and Raske 1989a, 1989b).

In the mid-1970s and early-1980s eastern larch beetles exhibited the first known landscape-level epidemics. These outbreaks, lasting five to six years each (Werner 1986; Langor and Raske 1988a), affected more than 3.3 million ha of tamarack forest in Alaska and killed more than 1.4 million $\mathrm{m}^{3}$ of tamarack in the Canadian Maritimes. While the extent of beetle activity and tamarack mortality was more than what Swaine would have predicted, the patterns followed predisposing actions of defoliators written about in his text (Swaine 1918). These eastern larch beetle epidemics followed episodes of repeated and wide-spread defoliation of tamaracks by spruce budworm (Choristoneura fumiferana (Clemens); Lepidoptera: Tortricidae), larch sawfly (Pristiphora erichsonii (Hartig); Hymenoptera: Tenthredinidae), larch budmoth (Zeiraphera Treitschke; Lepidoptera: Tortricidae), or larch casebearer (Coleophora laricella (Hübner); Lepidoptera: Coleophoridae) (Werner 1986; Langor and Raske 1989a, 1989b).

When attacking healthy tamaracks, eastern larch beetles will target a variety of tree sizes (Seybold et al. 2002) but demonstrate an initial preference for the largest trees (Hopkins 1909b; Werner 1986; Langor and Raske 1989a, 1989b; McKee 2015). In other bark beetles, the largest trees are shown to increase the reproductive success of parent beetles and facilitate the shifts between population phases (e.g., incipientepidemic to epidemic; Table 1; Amman 1972; Amman and Pace 1976; Humphreys 2000). Eastern larch beetles also exhibit improved reproductive success in larger diameter tamaracks (Werner 1986). Specific studies on host-insect interactions between eastern larch beetles and tamaracks that determine optimum reproductive success as a factor of host size are lacking, however. Defensive resinosis responses in colonised tamaracks exert an antixenotic effect on eastern larch beetle offspring (Werner 1986; Langor and Raske 1988b), but relationships between tree age, size, vigour, and beetle reproductive success are not yet fully elucidated (McKee 2015).

Similarly, while the predisposition of eastern larch beetle activity by defoliating insects has been well noted, the interactions between the eastern larch beetle and potential competitors have received limited study. Eastern larch beetles are often noted as the dominant or only species of bark beetle found within the main stem of colonised tamaracks during endemic and epidemic population phases (Dodge 1938; Langor 1991; Seybold et al. 2002). Relatively few species of bark beetles colonise tamarack, so potential competitors are limited to phloem-feeding species such as Polygraphus rufipennis (Kirby), Scolytus piceae (Swaine), Crypturgus pusillus (Gyllenhal), and Orthotomicus caelatus (Eichhoff) (Dodge 1938; Rose and Lindquist 1980; Wood 1982; Langor 1991). These species are all polyphagous, however, and are not exclusive colonisers of tamarack (Wood 1982). Resource partitioning may also minimise competitive interactions when larger species (e.g., eastern larch beetle) colonise the thicker phloem of the main stem while smaller species (e.g., Polygraphus rufipennis) take advantage of the thinner phloem in the upper stem and larger branches. 
Interactions between the eastern larch beetle and associated natural enemies and microorganisms are likewise only documented in a limited number of studies (Langor and Raske 1988b; Langor 1991). In general, it appears that overall mortality inflicted on developing eastern larch beetle larvae by parasitoid species such as Roptrocerus xylophagorum (Ratzburg) (Hymenoptera: Pteromalidae) can be significant (i.e., up to 37\%), although these are not expected to suppress outbreaking populations. Fungal pathogens can also be responsible for up to 15\% larval mortality (Langor and Raske 1988b), although the breadth and types of microorganisms associated with eastern larch beetles have not been well characterised (Jacobs et al. 1997). Additional studies on natural causes of eastern larch beetle mortality and how microbes may mediate insecthost dynamics are sorely needed.

Due to the limited number of landscape-scale outbreaks of eastern larch beetles, the mechanisms that precipitate the decline in beetle populations from epidemic back to endemic phases have not been determined (Table 1). One potential mechanism that may act to reduce the reproductive success of eastern larch beetles during epidemics includes the gradual increase in the level of host resistance remaining among living trees as less vigorous trees are culled from the forest, similar to the phenomenon exhibited in outbreaks of Douglas-fir beetle. It is possible that the resininduced toxicity of vigorous trees may act to curtail beetle reproductive success such that proportionately more tamaracks act as beetle sinks than beetle sources and eventually cause the collapse of beetle populations. Additionally, below-average winter temperatures may cause increased mortality to overwintering adult and sub-adult life-stages. Eastern larch beetles are extremely cold-hardy, however, with supercooling points of $-49^{\circ} \mathrm{C}$ and $-42^{\circ} \mathrm{C}$ for larvae and adults, respectively, in December (Venette and Walter 2008).

Because tamarack has not historically been managed for timber, there is a paucity of studies that have evaluated management tactics against eastern larch beetle (Seybold et al. 2002). Swaine's recommendations of timely sanitation of logging slash or storm-damaged material would appear to be sensible practices due to the beetle's preference for breeding in downed material, and could even be extended to the use of trap trees (Swaine 1918). No studies have evaluated silvicultural practices such as thinning in tamarack stands, although care would be needed to avoid injury to the shallow roots of tamaracks during such operations (Seybold et al. 2002). Pheromone and host-volatile blends can trap large numbers of beetles and could be incorporated into a programme of integrated pest management, although the characterisation of the pheromone profile of eastern larch beetle is still not complete (Baker et al. 1977; Barkawi et al. 2003).

Clearly, more research is required to fully understand the population dynamics of the eastern larch beetle (McKee 2015). The mechanisms by which it is able to maintain viable populations during the endemic phase (e.g., competition versus facilitation via other bark beetle species), and how beetles in the endemic phase interact with the resin defence system of tamarack, is not yet known. Similar to Douglas-fir beetle, the effects of sibling broods on the overall population dynamics of this insect are also not well understood (McKee 2015). Some studies report high levels of late-fall, cold-induced mortality to the sub-adult life-stages of the second sibling brood (Langor and Raske 1987b) that result in this brood contributing less than $1 \%$ to the reproductive adult beetle population (Langor 1987). In contrast, there is evidence to suggest that sibling broods can successfully overwinter (Simpson 1929; McKee 2015). Recent laboratory studies indicate that the reproductive potential of spring-emergent adult beetles from different sibling broods is equivalent under laboratory conditions, suggesting that altered voltinism in a changing climate could exacerbate outbreaks of this insect (F.R.M. and B.H.A., personal observation).

The potential for shifts in voltinism is currently being explored for the eastern larch beetle (McKee and Aukema 2015a, 2015b). Swaine thought most Dendroctonus species to be univoltine in Canada, without mention of physiological enforcing mechanisms. Reproductive diapause in the eastern larch beetle was previously thought to be obligate such that brood adults had to overwinter before becoming reproductively viable (Langor and Raske 1987a). As such, eastern larch beetles have been assumed to possess a univoltine lifecycle with only a single, spring-emergent reproductive generation per year (Hopkins 1909b, Langor and Raske 1987a). Recent evidence indicates that some insects within a population may lack an obligate 
reproductive diapause, as some brood adults can become reproductively mature without an overwintering period (McKee and Aukema 2015b). This trait may allow some insects to reproduce in a bivoltine or semivoltine manner given appropriate environmental conditions, although the possibility and frequency of this phenomenon under natural field conditions is still being evaluated (McKee 2015).

\section{The mountain pine beetle, Dendroctonus ponderosae}

Currently, the most significant bark beetle of concern to North American forests is the mountain pine beetle. The behaviour and brood productivity of mountain pine beetle at endemic levels is still not well understood (Bleiker et al. 2014), although it appears that endemic populations can be facilitated by species that are otherwise competitors at higher population densities (Table 1; Rankin and Borden 1991; Smith et al. 2011). Due to the extent and impact of mountain pine beetle at the landscape-scale, studies on factors influencing outbreak dynamics, such as changes in temperature or precipitation regimes, are much more abundant (Aukema et al. 2008; Chapman et al. 2012; Preisler et al. 2012; Sambaraju et al. 2012; Creeden et al. 2014).

One hundred years ago, mountain pine beetle was responsible for "several" large outbreaks in British Columbia's pine forests, and several more outbreaks have been recorded in the past century (Swaine 1918; Hopping and Mathers 1945; Aukema et al. 2006; Campbell et al. 2007; Hrinkevich and Lewis 2011). The most recent outbreak in British Columbia and Alberta is the largest in recorded history (Raffa et al. 2008), converting affected forests from carbon sinks to carbon sources (Kurz et al. 2008) and even impacting regional weather through concomitant reduced evapotranspiration (Maness et al. 2013). Severe host depletion has even forced the beetle into traditional non-hosts of spruce Picea glauca (Moench) Voss $\times P$. engelmannii Parry ex Engelmann in some areas (Huber et al. 2009; McKee et al. 2013). Of greater concern has been the gradual expansion of its geographic range in western Canada during the last several decades due to an increase in thermally benign habitat (Carroll et al. 2004). This is not unlike expansions seen in the United States of America into higher elevation five-needle pines (Logan and Powell 2001; Weed et al. 2013).

Range expansion by the mountain pine beetle has occurred northward (Sambaraju et al. 2012) and eastward over the northern Rocky Mountains (Robertson et al. 2009; de la Giroday et al. 2011, 2012) and across the Alberta Plateau (Janes et al. 2014; Tsui et al. 2014). Infestations are now established within the region where lodgepole pine (Pinus contorta latifolia (Engelmann) Critchfield), the primary host of the beetle (Safranyik and Carroll 2006), intermingles and hybridises with jack pine ( $P$. banksiana Lambert) (Cullingham et al. 2011), a suitable host for mountain pine beetle (Furniss and Schenk 1969; Cerezke 1995) and a major component of the North American boreal forest. There is grave concern that the insect could now move through the Canadian boreal forest to novel pine hosts of eastern North America (Cerezke 1995; Lusebrink et al. 2013; Erbilgin et al. 2014). In a recent review of the invasive potential of the mountain pine beetle, Safranyik et al. (2010) concluded that continued eastward expansion into the boreal forest was a significant probability. However, lack of knowledge regarding altered trophic interactions in novel habitats precluded the capacity to predict the rate of spread and subsequent impacts of the invading population. This point is particularly relevant since new evidence suggests that the defensive response (Clark et al. 2010, 2014), the ability of beetles to aggregate (Burke and Carroll 2016), and the ultimate productivity of the mountain pine beetle (Cudmore et al. 2010), in putatively "evolutionarily naïve" trees may be very different from expectations derived from the beetle's historic habitat.

\section{A changing landscape in the epidemiology and population dynamics of bark beetles}

Canada's forested landscape today covers 348 million ha, still harbouring a wide variety of species of bark beetles from coast to coast (Swaine 1918; Bright 1976). Defoliators such as spruce budworm ( $C$. fumiferana) join native bark beetles as significant disturbance agents in Canada's boreal forest (Royama 1984; Hicke et al. 2012). Yet the template on which these biotic disturbance 
agents exist is under accelerating change (Bentz et al. 2010; Gauthier et al. 2014). Current rates of global change, manifested by introductions of invasive species and warming climates, could not have been anticipated in Swaine's time.

The rates of introduction of invasive forest insect pests to North America are increasing (Work et al. 2005; Aukema et al. 2010). While Swaine omitted other wood and bark boring families such as the Buprestidae and Cerambycidae, he could not have anticipated the impacts or mitigation efforts precipitated by the arrivals of Asian longhorned beetle (Anaplophora glabripennis (Motschulsky); Coleoptera: Cerambycidae), the emerald ash borer (Agrilus planipennis Fairmaire; Coleoptera: Buprestidae), or the brown spruce longhorn beetle (Tetropium fuscum (Fabricius); Coleoptera: Cerambycidae), to Canada over the past decade. Mercifully, no exotic bark beetles have had such pronounced effects on Canadian natural and urban forests to date, although the introduction of other invasive species has altered the population dynamics of some natives.

Swaine could not have foreseen that invasive species would cause some of the "neutral" species he highlighted to become threatened with extinction or synonymous with mass mortality within a century, for example. The eastern ash bark beetle (Hylesinus aculeatus (Say); Coleoptera: Curculionidae) was noted throughout the range of ash in eastern Canada (Swaine 1918). Now, the insect is listed at "high risk" due to the widespread mortality of ash (Fraxinus Linnaeus; Oleaceae) in North America caused by the emerald ash borer (Gandhi and Herms 2010). On elms, the innocuous and native elm bark beetle $H$. rufipes was "not known to cause any injury to living trees". At the time of Swaine's work, a malady among elms had been noted in Europe but it was not until the 1920s that the Dutch elm disease pathogen Ophiostoma ulmi (Buisman) Melin and Nannfeldt (Ophiostomataceae) was identified (Brasier and Buck 2001). In ensuing years this pathogen arrived in North America with another bark beetle vector identified as Scolytus multistriatus (Marsham). Now inextricably linked with a subsequent virulent pathogen Ophiostoma novo-ulmi Brasier in the complex, H. rufipes unfortunately can no longer be considered a neutral species as Swaine had it placed (Collins et al. 1936; Anderson and Holliday 2003).
Likewise, Swaine probably did not give thought to native bark beetles of Canada that might eventually display new dynamics in other regions of the world. The red turpentine beetle (Dendroctonus valens LeConte) was listed as an "important assistant" of mountain pine beetle in ponderosa pine (Pinus ponderosae Douglas ex Lawson), where it could kill "patches of bark at the base of living pines and spruces" (Swaine 1918). In the 1980 s, this insect was accidentally introduced from North America to China, where it is now an aggressive tree-killing bark beetle on pines devoid of any coevolutionary association (Yan et al. 2005; Sun et al. 2013). There is now grave concern the beetle could return to North America with novel fungi, and create a similar pandemic on pines here (Lu et al. 2009; Taerum et al. 2013).

\section{Conclusion: advice from the past}

Despite stark differences in environmental conditions between the turns of the 20th and 21st centuries that affect bark beetle population dynamics, we conclude by noting two adages from Swaine related to management strategies that still hold true for today and into the future. First, despite the broad generalisations in places in his text, Swaine reminded the reader that each management scenario is unique, as each prescription for control depends "upon the species of beetles, and partly upon local conditions". Richmond (1986) elaborated that forest ecologists should "not confuse an issue in eastern North America with a similar problem in the west. While the species of insect may be the same, most other factors will be totally different". Who could have known such a statement would be so apropos in researching solutions to range expansions of mountain pine beetle, unforeseen a century ago?

Familiarize yourself with your predecessors' mistakes, and don't repeat them. Don't be ashamed of your mistakes - profit by them (H.A. Richmond 1986).

While the first recommendation advocates for context-dependent management, it prompts the question of what recommendations are due in each situation. Hence, Swaine's second adage most critically stipulated that all activities "should be undertaken under the direction of a competent 
forest entomologist". Swaine felt strongly about training the next generation of forest health professionals; in fact, Swaine taught one of the first entomology courses in Canada at Macdonald College with Professor William Lockhead in 1907 (Johnstone 1991). Canada has benefited from an exceptionally rich heritage of bark beetle ecologists in addition to Swaine over the past century: Richmond, Hopping, McCambridge, Reid, Shepherd, Whitney, Safranyik, Shore, de Groot, Borden, Lindgren, and others. A synthesis of their accomplishments is beyond the scope of this work, and perhaps not even appropriate: Richmond encouraged future generations to dwell on their forerunners' foibles. "Familiarize yourself with your predecessors' mistakes, and don't repeat them. Don't be ashamed of your mistakes profit by them" (Richmond 1986). This collaborative article was authored by a duo of graduate students and their professors. With accelerating rates of species invasions and changing climates, the need for well-qualified forest managers will not diminish in the next century.

\section{Acknowledgements}

The authors are indebted to a global bark beetle community that extends beyond Canada and continues to make noteworthy advances in bark beetle ecology in the face of a rapidly changing world. Given the principle nanos gigantum humeris insidentes (discovering truth by building on previous discoveries), they regret that many worthy papers are not cited in this review. The authors appreciate the editorial assistance of A.M. Wilke (University of Minnesota) and the assistance finding the only known photograph of J.M. Swaine by M.M. Furniss (United States Forestry Service retired; University of Idaho). Helpful comments on previous versions of this work were provided by D. Langor and R. Alfaro (Canadian Forest Service), D. Rosenberger (University of Minnesota), and two anonymous reviewers. Thanks to Les Safranyik for sharing his knowledge of spruce beetle natural history. Funding for this work was provided in part by United States Forest Service Evaluation Monitoring project NC-EM-B-12-01, the University of Minnesota Agricultural Experimental Station, and the British Columbia Future Forest Ecosystems Science Council.

\section{References}

Amman, G.D. 1972. Mountain pine beetle brood production in relation to thickness of lodgepole pine phloem. Journal of Economic Entomology, 65: $138-140$.

Amman, G.D. and Pace, V.E. 1976. Optimum egg gallery densities for the mountain pine beetle in relation to lodgepole pine phloem thickness. Research Note INT-209. United States Department of Agriculture - Forest Service, Intermountain Forest and Range Experiment Station, Ogden, Utah, United States of America.

Anderbrant, O. 1989. Reemergence and second brood in the bark beetle Ips typographus. Holarctic Ecology, 12: 494-500.

Anderson, P.L. and Holliday, N.J. 2003. Distribution and survival of overwintering adults of the Dutch elm disease vector, Hylurgopinus rufipes (Coleoptera: Scolytidae), in American elm trees in Manitoba. Agricultural and Forest Entomology, 5: 137-144.

Anderson, R.F. 1948. Host selection by the pine engraver. Journal of Economic Entomology, 41: 596-602.

Andrewartha, H.G. and Birch, L.C. 1954. The distribution and abundance of animals. University of Chicago Press, Chicago, Illinois, United States of America.

Atkins, M.D. and McMullen, L.H. 1960. On certain factors influencing Douglas-fir beetle populations. In Fifth World Forestry Congress Proceedings. University of Washington, Seattle, Washington, United States of America. Pp. 857-859.

Aukema, B.H., Carroll, A.L., Zheng, Y., Zhu, J., Raffa, K.F., Moore, R.D., et al. 2008. Movement of outbreak populations of mountain pine beetle: influences of spatiotemporal patterns and climate. Ecography, 31: 348-358.

Aukema, B.H., Carroll, A.L., Zhu, J.K., Raffa, F., Sickley, T.A., and Taylor, S.W. 2006. Landscape level analysis of mountain pine beetle in British Columbia, Canada: spatiotemporal development and spatial synchrony within the present outbreak. Ecography, 29: 427-441.

Aukema, J.E., McCullough, D.G., Von Holle, B., Liebhold, A.M., Britton, K., and Frankel, S.J. 2010. Historical accumulation of nonindigenous forest pests in the continental United States. Bioscience, 60: $886-897$.

Aukema, B.H. and Raffa, K.F. 2004. Behavior of adult and larval Platysoma cylindrica (Coleoptera: Histeridae) and larval Medetera bistriata (Diptera: Dolichopodidae) during subcortical predation of Ips pini (Coleoptera: Scolytidae). Journal of Insect Behavior, 17: 115-128.

Aukema, B.H., Werner, R.A., Haberkern, K.E., Illman, B.L., Clayton, M.K., and Raffa, K.F. 2005. Quantifying sources of variation in the frequency of fungi associated with spruce beetles: implications for hypothesis testing and sampling methodology in bark beetle-symbiont relationships. Forest Ecology and Management, 217: 187-202. 
Ayres, B.D., Ayres, M.P., Abrahamson, M.D., and Teale, S.A. 2001. Resource partitioning and overlap in three sympatric species of Ips bark beetles (Coleoptera: Scolytidae). Oecologia, 128: 443-453.

Baker, B.H., Hostetler, B.B., and Furniss, M.M. 1977. Response of eastern larch beetle (Coleoptera: Scolytidae) in Alaska to its natural attractant and to Douglas-fir beetle pheromones. The Canadian Entomologist, 109: 289-294.

Bale, J.S., Masters, G.J., Hodkinson, I.D., Awmack, C., Bezemer, T.M., Brown, V.K., et al. 2002. Herbivory in global climate change research: direct effects of rising temperature on insect herbivores. Global Change Biology, 8: 1-16.

Barber, V.A., Juday, G.P., and Finney, B.P. 2000. Reduced growth of Alaskan white spruce in the twentieth century from temperature-induced drought stress. Nature, 406: 668-673.

Barkawi, L.S., Franke, W., and Blomquist, G.J. 2003. Frontalin: de novo biosynthesis of an aggregation pheromone component by Dendroctonus spp. bark beetles (Coleoptera: Scolytidae). Insect Biochemistry \& Molecular Biology, 33: 773-788.

Barron, A.B. 2001. The life and death of Hopkins' hostselection principle. Journal of Insect Behavior, 14: 725-737.

Beal, J.A. 1943. Relation between tree growth and outbreaks of the Black Hills beetle. Journal of Forestry, 41: 359-366.

Benoit, P. and Blais, R. 1988. The effects of defoliation by the larch casebearer on the radial growth of tamarack. The Forestry Chronicle, 64: 190-192.

Bentz, B.J., Logan, J.A., and Amman, G.D. 1991. Temperature-dependent development of the mountain pine beetle (Coleoptera, Scolytidae) and simulation of its phenology. The Canadian Entomologist, 123: 1083-1094.

Bentz, B.J. and Munson, A.S. 2000. Spruce beetle population suppression in northern Utah. Western Journal of Applied Forestry, 15: 122-128.

Bentz, B.J., Régnière, J., Fettig, C.J., Hansen, E.M., Hayes, J.L., Hicke, J.A., et al. 2010. Climate change and bark beetles of the western United States and Canada: direct and indirect effects. Bioscience, 60: 602-613.

Berg, E.E., Henry, J.D., Fastie, C.L., Volder, A.D.D., and Matsuoka, S.M. 2006. Spruce beetle outbreaks on the Kenai Peninsula, Alaska, and Kluane National park and reserve, Yukon Territory: relationship to summer temperatues and regional differences in disturbance regimes. Forest Ecology and Management, 227: 219-232.

Blackman, M.W. 1931. The Black Hills beetle (Dendroctonus ponderosae Hopk.). New York State College of Forestry at Syracuse University, Technical Publication, 36: 1-97.

Bleiker, K.P., Heron, R.J., Braithwaite, E.C., and Smith, G.D. 2013. Preemergence mating in the mass-attacking bark beetle, Dendroctonus ponderosae (Coleoptera: Curculionidae). The Canadian Entomologist, 145: 12-19.
Bleiker, K.P., O’Brien, M.R., Smith, G.D., and Carroll, A.L. 2014. Characterisation of attacks made by the mountain pine beetle (Coleoptera: Curculionidae) during its endemic population phase. The Canadian Entomologist, 146: 271-284.

Bohlmann, J., Gershenzon, J., and Aubourg, S. 2000. Biochemical, molecular genetic, and evolutionary aspects of defense-related terpenoids in conifers. Recent Advances in Phytochemistry, 34: 109-149.

Boone, C.K., Aukema, B.H., Bohlmann, J., Carroll, A.L., and Raffa, K.F. 2011. Efficacy of tree defense physiology varies with bark beetle population density: a basis for positive feedback in eruptive species. Canadian Journal of Forest Research, 41: 1174-1188.

Boone, C.K., Six, D.L., Zheng, Y.B., and Raffa, K.F. 2008. Parasitoids and dipteran predators exploit volatiles from microbial symbionts to locate bark beetles. Environmental Entomology, 37: 150-161.

Borden, J.H. 1989. Semiochemicals and bark beetle populations: exploitation of natural phenomena by pest management strategists. Holarctic Ecology, 12: 501-510.

Borden, J.H., Birmingham, A.L., and Burleigh, J.S. 2006. Evaluation of the push-pull tactic against the mountain pine beetle using verbenone and non-host volatiles in combination with pheromone-baited trees. The Forestry Chronicle, 82: 579-590.

Borden, J.H., Gries, G., Chong, L.J., Werner, R.A., Holsten, E.H., Wieser, H., et al. 1996. Regionallyspecific bioactivity of two new pheromones for Dendroctonus rufipennis (Kirby) (Col., Scolytidae). Journal of Applied Entomology, 120: 321-326.

Brasier, C.M. and Buck, K.W. 2001. Rapid evolutionary changes in a globally invading fungal pathogen (Dutch elm disease). Biological Invasions, 3: 223-233.

Bright, D.E. 1976. The insects and arachnids of Canada. Part 2. The bark beetles of Canada and Alaska (Coleoptera: Scolytidae). Publication 1573. Canadian Department of Agriculture, Ottawa, Ontario, Canada.

Bright, D.E. 2014. A catalog of Scolytidae and Platypodidae (Coleoptera), supplement 3 (2000-2010), with notes on subfamily and tribal reclassifications. Insecta Mundi, 356: 1-336.

British Columbia Ministry of Forest and Range. 2012. Spruce beetle Dendroctonus rufipennis. Insects of the southern interior forest region [online]. British Columbia Ministry of Forests and Range, Southern Interior Region, Forest Health Pamphlet 3. Available from http://web.forestry.ubc.ca/fetch21/Z-PDF-pestinfo-folder/SBpamphlet-Spruce $\% 20$ beetle $\% 20 \mathrm{in} \%$ 20BC.pdf [accessed 6 January 2016].

Brown, A.W.A. 1940. A note on the gross estimate of forest insect damage in Canada. Forestry Chronicle, 16: $249-254$.

Burke, J.L. and Carroll, A.L. 2016. The influence of variation in host tree monoterpene composition on secondary attraction by an invasive bark beetle: implications for range expansion and potential host shift by the mountain pine beetle. Forest Ecology and Management, 359: 59-64. 
Campbell, E.M., Alfaro, R.I., and Hawkes, B. 2007. Spatial distribution of mountain pine beetle outbreaks in relation to climate and stand characteristics: a dendroecological analysis. Journal of Integrative Plant Biology, 49: 168-178.

Cardoza, Y.J., Klepzig, K.D., and Raffa, K.F. 2006. Bacteria in oral secretions of an endophytic insect inhibit antagonistic fungi. Ecological Entomology, 31: 636-645.

Carroll, A.L., Shore, T.L., and Safranyik, L. 2006. Direct control: theory and practice. In The mountain pine beetle: a synthesis of biology, management, and impacts on lodgepole pine. Edited by L. Safranyik and B. Wilson. Natural Resources Canada, Pacific Forestry Centre, Victoria, British Columbia, Canada. Pp. 155-172.

Carroll, A.L., Taylor, S.W., Régniere, J., and Safranyik, L. 2004. Effects of climate change on range expansion by the mountain pine beetle in British Columbia. In Challenges and solutions: proceedings of the mountain pine beetle symposium. Kelowna, British Columbia, Canada October 30-31, 2003. Information Report BC-X-399. Edited by T.L. Shore, J.E. Brooks, and J.E. Stone. Canadian Forest Service, Pacific Forestry Centre, Victoria, British Columbia, Canada. Pp. 223-232.

Cerezke, H.F. 1995. Egg gallery, brood production, and adult characteristics of mountain pine beetle, Dendroctonus ponderosae Hopkins (Coleoptera, Scolytidae), in three pine hosts. The Canadian Entomologist, 127: 955-965.

Chapman, T.B., Veblen, T.T., and Schoennagel, T. 2012. Spatiotemporal patterns of mountain pine beetle activity in the southern Rocky Mountains. Ecology, 93: 2175-2185.

Clark, E.L., Carroll, A.L., and Huber, D.P.W. 2010. Differences in the constitutive terpene profile of lodgepole pine across a geographical range in British Columbia, and correlation with historical attack by mountain pine beetle. The Canadian Entomologist, 142: 557-573.

Clark, E.L., Pitt, C., Carroll, A.L., Lindgren, B.S., and Huber, D.P.W. 2014. Comparison of lodgepole and jack pine resin chemistry: implications for range expansion by the mountain pine beetle, Dendroctonus ponderosae (Coleoptera: Curculionidae). PeerJ, 2: e240. doi:10.7717/peerj.240.

Collins, C.W., Buchanan, W.D., Whitten, R.R., and Hoffmann, C.H. 1936. Bark beetles and other possible insect vectors of the Dutch elm disease Ceratostomella ulmi (Schwarz) Buisman. Journal of Economical Entomology, 29: 169-176.

Creeden, E.P., Hicke, J.A., and Buotte, P.C. 2014. Climate, weather, and recent mountain pine beetle outbreaks in the western United States. Forest Ecology and Management, 312: 239-251.

Cudmore, T.J., Bjorklund, N., Carroll, A.L., and Lindgren, B.S. 2010. Climate change and range expansion of an aggressive bark beetle: evidence of higher beetle reproduction in naive host tree populations. Journal of Applied Ecology, 47: 1036-1043.
Cullingham, C.I., Cooke, J.E.K., Dang, S., Davis, C.S., Cooke, B.J., and Coltman, D.W. 2011. Mountain pine beetle host-range expansion threatens the boreal forest. Molecular Ecology, 20: 2157-2171.

Davidson, R.W. 1955. Wood-staining fungi associated with bark beetles in Engelmann spruce in Colorado. Mycologia, 47: 58-67.

de la Giroday, H.-M.C., Carroll, A.L., and Aukema, B.H. 2012. Breach of the northern Rocky Mountain geoclimatic barrier: initiation of range expansion by the mountain pine beetle. Journal of Biogeography, 39: 1112-1123.

de la Giroday, H.-M.C., Carroll, A.L., Lindgren, B.S., and Aukema, B.H. 2011. Incoming! Association of landscape features with dispersing mountain pine beetle populations during a range expansion event in western Canada. Landscape Ecology, 26: 1097-1110.

DiGuistini, S., Wang, Y., Liao, N.Y., Taylor, G., Tanguay, P., Feau, N., et al. 2011. Genome and transcriptome analyses of the mountain pine beetlefungal symbiont Grosmannia clavigera, a lodgepole pine pathogen. Proceedings of the National Academy of Sciences of the United States of America, 108: 2504-2509.

Dodds, K.J., Graber, C., and Stephen, F.M. 2001. Facultative intraguild predation by larval Cerambycidae (Coleoptera) on bark beetle larvae (Coleoptera: Scolytidae). Environmental Entomology, 30: 17-22.

Dodge, H.R. 1938. The bark beetles of Minnesota (Coleoptera: Scolytidae). Technical Bulletin 132. Univerisity of Minnesota Agricultural Experiment Station, St. Paul, Minnesota, United States of America.

Dworschak, K., Gruppe, A., and Schopf, R. 2014. Survivability and post-diapause fitness in a scolytid beetle as a function of overwintering developmental stage and the implications for population dynamics. Ecological Entomology, 39: 519-526.

Dyer, E.D.A. 1969. Influence of temperature inversion on development of spruce beetle, Dendroctonus obesus (Mannerheim) (Coleoptera: Scolytidae). Journal of the Entomological Society of British Columbia, 66: 41-45.

Dyer, E.D.A. and Hall, P.M. 1977. Factors affecting larval diapause in Dendroctonus rufipennis (Coleoptera: Scolytidae). The Canadian Entomologist, 109: 1485-1490.

Dyer, E.D.A. and Taylor, D.W. 1971. Spruce beetle brood production in logging slash and wind-thrown trees in British Columbia. Information Report BC-X-062. Pacific Forest Research Centre, Environment Canada, Canadian Forestry Service, Victoria, British Columbia, Canada.

Erbilgin, N., Krokene, P., Kamme, T., and Christiansen, E. 2007. A host monoterpene influences Ips typographus (Coleoptera: Curculionidae, Scolytinae) responses to its aggregation pheromone. Agricultural and Forest Entomology, 9: 135-140.

Erbilgin, N., Ma, C., Whitehouse, C., Shan, B., Najar, A., and Evenden, M. 2014. Chemical similarity between historical and novel host plants promotes range and host expansion of the mountain pine beetle in a naive host ecosystem. New Phytologist, 201: 940-950. 
Fettig, C.J., Klepzig, K.D., Billings, R.F., Munson, A.S., Nebeker, T.E., Negrón, J.F., and Nowak, J.T. 2007. The effectiveness of vegetation management practices for prevention and control of bark beetle infestations in coniferous forests of the western and southern United States. Forest Ecology and Management, 238: 24-43.

Franceschi, V.R., Krokene, P., Christiansen, E., and Krekling, T. 2005. Anatomical and chemical defenses of conifer bark against bark beetles and other pests [review]. New Phytologist, 167: 353-375.

Fredricks, S.E. and Jenkins, M.J. 1988. Douglas-fir beetle (Dendroctonus pseudotsugae Hopkins, Coleoptera: Scolytidae) brood production on Douglas-fir defoliated by western spruce budworm (Choristoneura occidentalis Freeman, Lepidoptera: Tortricidae) on Logan Canyon, Utah. Great Basin Naturalist, 48: 348-351.

Furniss, M.M. 1976. Controlled breeding, comparative anatomy and bionomics of Dendroctonus simplex LeConte and Dendroctonus pseudotsugae Hopkins (Coleoptera: Scolytidae). Department of Entomology Anniversary Publication 15. University of Idaho, Department of Entomology, Moscow, Idaho, United States of America.

Furniss, M.M., Baker, B.H., and Hostetler, B.B. 1976. Aggregation of spruce beetles (Coleoptera) to seudenol and repression of attraction by methylcyclohezenone in Alaska. The Canadian Entomologist, 108: 1297-1302.

Furniss, M.M., Livingston, R.L., and McGregor, M.D. 1981. Development of a stand susceptibility classification for Douglas-fir beetle. In Hazard-rating systems in forest insect management: symposium proceedings. General Technical Report WO-27. Edited by R.L. Hedden, S.J. Barras, and J. Coster. United States Department of Agriculture - Forest Service, Athens, Georgia, United States of America. Pp. 115-128.

Furniss, M.M., McGregor, M.D., Foiles, M.W., and Partridge, A.D. 1979. Chronology and characteristics of a Douglas-fir beetle outbreak in northern Idaho. General Technical Report INT-59. United States Department of Agriculture - Forest Service, Intermountain Forest and Range Experiment Station, Ogden, Utah, United States of America.

Furniss, M.M. and Schenk, J.A. 1969. Sustained natural infestations by the mountain pine beetle in seven new Pinus and Picea hosts. Journal of Economic Entomology, 62: 518-519.

Furniss, R.L. and Carolin, V.M. 1977. Western forest insects. Miscellaneous Publication 1339. United States Department of Agriculture - Forest Service, Pacific Northwest Forest and Range Research Station, Portland, Oregon, United States of America.

Gandhi, K.J.K. and Herms, D.A. 2010. North American arthropods at risk due to widespread Fraxinus mortality caused by the alien emerald ash borer. Biological Invasions, 12: 1839-1846.
Gara, R.I., Werner, R.A., Whitmore, M.C., and Holsten, E.H. 1995. Arthropod associates of the spruce beetle Dendroctonus rufipennis (Kirby) (Col., Scolytidae) in spruce stands of south-central and interior Alaska. Journal of Applied Entomology, 119: 585-590.

Garbutt, R., Hawkes, B., and Allen, E. 2006. Spruce beetle and the forests of the southwest Yukon. Information Report BC-X-406. Natural Resources Canada, Canadian Forest Service, Pacific Forestry Centre, Victoria, British Columbia, Canada.

Garrison-Johnston, M.T., Moore, J.A., Cook, S.P., and Niehoff, G.J. 2003. Douglas-fir beetle infestations are associated with certain rock and stand types in the inland northwestern United States. Environmental Entomology, 32: 1354-1363.

Gauthier, S., Bernier, P., Burton, P.J., Edwards, J., Isaac, K., Isabel, N., et al. 2014. Climate change vulnerability and adaptation in the managed Canadian boreal forest. Environmental Reviews, 22: 256-285.

Gillette, N.E., Mehmel, C.J., Webster, J.N., Mori, S.R., Erbilgin, N., Wood, D.L., et al. 2009. Aerially applied methylcyclohexenone-releasing flakes protect Pseudotsuga menziesii stands from attack by Dendroctonus pseudotsugae. Forest Ecology and Management, 257: 1231-1236.

Gries, G., Borden, J.H., Gries, R., Lafontaine, J.P., Dixon, E.A., Wieser, H., et al. 1992. 4-methylene6,6-dimethylbicycol[3.1.1]hept-2-ene (verbenene): new aggregation pheromone of the scolytid beetle Dendroctonus rufipennis. The Science of Nature Naturwissenschaften, 79: 367-368.

Gries, G., Pierce, H.D., Lindgren, B.S., and Borden, J.H. 1988. New techniques for capturing and analyzing semiochemicals for scolytid beetles (Coleoptera: Scolytidae). Journal of Economical Entomology, 81: 1715-1720.

Haberkern, K.E. and Raffa, K.F. 2003. Phloeophagous and predaceous insects responding to synthetic pheromones of bark beetles inhabiting white spruce stands in the great lakes region. Journal of Chemical Ecology, 29: 1651-1663.

Hadley, K.S. and Veblen, T.T. 1993. Stand response to western spruce budworm and Douglas-fir bark beetle outbreaks, Colorado Front Range. Canadian Journal of Forest Research, 23: 479-491.

Hansen, E.M. and Bentz, B.J. 2003. Comparison of reproductive capacity among univoltine, semivotine and re-emerged parent spruce beetles (Coleoptera: Scolytidae). The Canadian Entomologist, 135: 697-712.

Hansen, E.M., Bentz, B.J., Powell, J.A, Gray, D.R., and Vandygriff, J.C. 2011. Prepupal diapause and instar IV developmental rates of the spruce beetle, Dendroctonus rufipennis (Coleoptera: Curculionidae, Scolytinae). Journal of Insect Physiology, 57: 1347-1357.

Hansen, E.M., Bentz, B.J., and Turner, D.L. 2001. Physiological basis for flexible voltinism in the spruce beetle (Coleoptera: Scolytidae). The Canadian Entomologist, 133: 805-817. 
Hard, J.S. 1987. Vulnerability of white spruce with slowly expanding lower boles on dry, cold sites to early seasonal attack by spruce beetles in south central Alaska. Canadian Journal of Forest Research, 17: 428-435.

Hard, J.S., Werner, R.A., and Holsten, E.H. 1983. Susceptibility of white spruce to attack by spruce beetles during the early years of an outbreak in Alaska. Canadian Journal of Forest Research, 13: 678-684.

Hicke, J.A., Allen, C.D., Desai, A.R., Dietze, M.C., Hall, R.J., Hogg, E.H., et al. 2012. Effects of biotic disturbances on forest carbon cycling in the United States and Canada. Global Change Biology, 18: 7-34.

Hofstetter, R.W. and Moser, J.C. 2014. The role of mites in insect-fungus associations. Annual Review of Entomology, 59: 537-557.

Holsten, E.H., Thier, R.W., Munson, A.S., and Gibson, K.E. 1999. The spruce beetle. Forest Insect \& Disease Leaflet 127. United States Department of Agriculture, Forest Service, Pacific Northwest Forest and Range Experiment Station, Portland, Oregon, United States of America.

Hopkins, A.D. 1909a. Contributions toward a monograph of the scolytid beetles. United States Department of Agriculture, Bureau of Entomology, Technical Series, 17: 1-164.

Hopkins, A.D. 1909b. The eastern larch beetle. The Douglas fir beetle. Bulletin 83, part 1. United States Department of Agriculture - Bureau of Entomology, Washington, District of Columbia, United States of America.

Hopkins, A.D. 1916. Economic investigations of the scolytid and timber beetles of North America. In United States Department of Agriculture Program of Work for 1917. United States Government Printing Office, Washington, District of Columbia, United States of America. P. 353.

Hopkins, A.D. 1920. The bioclimatic law. Monthly Weather Review, 48: 355-355.

Hopkins, A.D. 1938. Bioclimatics: a science of life and climate relations. United States Department of Agriculture Miscellaneous Publication 280. United States Government Printing Office, Washington, District of Columbia, United States of America.

Hopping, G.R. and Beal, G. 1948. The relation of diameter of lodgepole pine to incidence of attack by the bark beetle Dendroctonus monticolae Hopkins. Forestry Chronicle, 24: 1-5.

Hopping, G.R. and Mathers, W.G. 1945. Observations on outbreaks and control of mountain pine beetle in the lodgepole pine stands of western Canada. Forestry Chronicle, 21: 1-11.

Hrinkevich, K. and Lewis, K.J. 2011. Northern range limit mountain pine beetle outbreak dynamics in mixed sub-boreal forests of British Columbia. Ecosphere, 2, article 116. doi:10.1890/ES1100150.1 .
Huber, D.P.W., Aukema, B.H., Hodgkinson, R.S., and Lindgren, B.S. 2009. Successful colonization, reproduction, and new generation emergence in live interior hybrid spruce Picea engelmannii x glauca by mountain pine beetle Dendroctonus ponderosae. Agricultural and Forest Entomology, 11: 83-89.

Huber, D.P.W., Ralph, S., and Bohlmann, J. 2004. Genomic hardwiring and phenotypic plasticity of terpenoid-based defenses in conifers. Journal of Chemical Ecology, 30: 2399-2418.

Humphreys, N. 2000. Douglas-fir beetle in British Columbia. Forest Pest Leaflet 14. Natural Resources Canada, Canadian Forest Service, Pacific Forestry Centre, Victoria, British Columbia, Canada.

Humphreys, N. and Safranyik, L. 1993. Spruce beetle. Forest Pest Leaflet 13. Natural Resources Canada, Canadian Forest Service, Pacific Forestry Centre, Victoria, British Columbia, Canada.

Intergovernmental Panel on Climate Change. 2014. Climate change 2014: impacts, adaptation, and vulnerability. Part A: global and sectoral aspects. Contribution of working group II to the fifth assessment report of the intergovernmental panel on climate change. Edited by C.B. Field, V.R. Barros, D.J. Dokken, K.J. Mach, M.D. Mastrandrea, T.E. Bilir, et al. Cambridge University Press, Cambridge, United Kingdom.

Jacobs, K., Wingfield, M.J., and Bergdahl, D.R. 1997. A new Ophiostoma species with a Graphium anamorph from Larix laricina in eastern North America. Mycologia, 89: 332-338.

Janes, J.K., Li, Y., Keeling, C.I., Yuen, M.M.S., Boone, C.K., Cooke, J.E.K., et al. 2014. How the Mountain pine beetle (Dendroctonus ponderosae) breached the Canadian Rocky Mountains. Molecular Biology and Evolution, 31: 1803-1815.

Johnson, N.E. and Belluschi, P.G. 1969. Host-finding behavior of the Douglas-fir beetle. Journal of Forestry, 67: 290-295.

Johnstone, K. 1991. Forest entomology and pathology, 1918-1945. In Timber and trauma: 75 years with the Federal Forestry Service, 1899-1974. Forestry Canada, Ottawa, Ontario, Canada. Pp. 106-111.

Kegley, S.J., Livingston, R.L., and Gibson, K.E. 1997. Pine engraver, Ips pini, in the western United States. Forest Insect and Disease Leaflet 122. United States Department of Agriculture, Forest Service, Washingon, District of Columbia, United States of America.

Kim, D.N. and Miller, M.C. 1981. A phloem sandwich unit for observing bark beetles, associated predators, and parasites. Research Note SO-269. Southern Forest Experiment Station, United States Department of Agriculture, Forest Service, New Orleans, Louisiana, United States of America.

Kirkendall, L.R. 1983. The evolution of mating systems in bark and ambrosia beetles (Coleoptera: Scolytidae and Platypodidae). Zoological Journal of the Linnean Society, 77: 293-352. 
Klepzig, K.D., Adams, A.S., Handelsman, J., and Raffa, K.F. 2009. Symbioses: a key driver of insect physiological processes, ecological interactions, evolutionary diversification, and impacts on humans. Environmental Entomology, 38: 67-77.

Knight, F.B. 1960. Measurement of Engelmann spruce beetle populations. Ecology, 41: 249-252.

Knight, F.B. 1961. Variation in the life history of the Engelmann spruce beetle. Annals of the Entomological Society of America, 54: 209-214.

Kozlowski, T.T. 1982. Water supply and tree growth. Part 1. Water deficits. Forestry Abstracts, 43: 57-95.

Kurz, W.A., Dymond, C.C., Stinson, G., Rampley, G.J., Neilson, E.T., Carroll, A.L., et al. 2008. Mountain pine beetle and forest carbon feedback to climate change. Nature, 452: 987-990.

Laidlaw, W.G., Prenzel, B.G., Reid, M.L., Fabris, S., and Wieser, H. 2003. Comparison of the efficacy of pheromone-baited traps, pheromone-baited trees, and felled trees for the control of Dendroctonus pseudostugae (Coleoptera: Scolytidae). Environmental Entomology, 32: 477-483.

Langor, D.W. 1987. Flight muscle changes in the eastern larch beetle, Dendroctonus simplex LeConte (Coleoptera: Scolytidae). The Coleopterists Bulletin, 41: 351-357.

Langor, D.W. 1991. Arthropods and nematodes co-occurring with the eastern larch beetle, Dendroctonus simplex (Col.: Scolytidae), in Newfoundland. Entomophaga, 36: 303-313.

Langor, D.W. and Raske, A.G. 1987a. Emergence, host attack, and overwintering behavior of the eastern larch beetle, Dendroctonus simplex LeConte (Coleoptera: Scolytidae), in Newfoundland. The Canadian Entomologist, 119: 975-983.

Langor, D.W. and Raske, A.G. 1987b. Reproduction and development of the eastern larch beetle, Dendroctonus simplex LeConte (Coleoptera: Scolytidae), in Newfoundland. The Canadian Entomologist, 119: 985-992.

Langor, D.W. and Raske, A.G. 1988a. Annotated bibliography of the eastern larch beetle, Dendroctonus simplex LeConte (Coleoptera: Scolytidae). Information Report N-X-266. Canadian Forest Service, Newfoundland Forestry Centre, St. John's, Newfoundland and Labrador, Canada.

Langor, D.W. and Raske, A.G. 1988b. Mortality factors and life tables of the eastern larch beetle, Dendroctonus simplex (Coleoptera: Scolytidae), in Newfoundland. Environmental Entomology, 17: 959-963.

Langor, D.W. and Raske, A.G. 1989a. The eastern larch beetle, another threat to our forests (Coleoptera: Scolytidae). The Forestry Chronicle, 65: 276-279.

Langor, D.W. and Raske, A.G. 1989b. A history of the eastern larch beetle, Dendroctonus simplex (Coleoptera: Scolytidae), in North America. Great Lakes Entomologist, 22: 139-154.

Lejeune, R.R., McMullen, L.H., and Atkins, M.D. 1961. The influence of logging on Douglas-fir beetle populations. The Forestry Chronicle, 37: 308-314.
Lessard, E.D. and Schmid, J.M. 1990. Emergence, attack densities, and host relationships for the Douglas-fir beetle (Dendroctonus pseudotsugae Hopkins) in northern Colorado. Great Basin Naturalist, 50: 333-338.

Lewinsohn, D., Lewinsohn, E., Bertagnolli, C.L., and Patridge, A.D. 1994. Blue-stain fungi and their transport structures on the Douglas-fir beetle. Canadian Journal of Forest Research, 24: 2275-2283.

Lieutier, F., Yart, A., and Salle, A. 2009. Stimulation of tree defenses by ophiostomatoid fungi can explain attack success of bark beetles on conifers. Annals of Forest Science, 66: 801. doi:10.1051/forest/ 2009066.

Lindgren, B.S. and Raffa, K.F. 2013. Evolution of tree killing in bark beetles (Coleoptera: Curculionidae): trade-offs between the maddening crowds and a sticky situation. The Canadian Entomologist, 145: 471-495.

Logan, J.A. and Powell, J.A. 2001. Ghost forests, global warming, and the mountain pine beetle (Coleoptera: Scolytidae). American Entomologist, 47: 160-173.

Lu, K.C., Allen, D.G., and Bollen, W.B. 1957. Association of yeasts with the Douglas-fir beetle. Forest Science, 3: 336-343.

Lu, M., Zhou, X.D., De Beer, Z.W., Wingfield, M.J., and Sun, J.H. 2009. Ophiostomatoid fungi associated with the invasive pine-infesting bark beetle, Dendroctonus valens, in China. Fungal Diversity, 38: 133-145.

Lusebrink, I., Erbilgin, N., and Evenden, M.L. 2013. The lodgepole $\times$ jack pine hybrid zone in Alberta, Canada: a stepping stone for the mountain pine beetle on its journey east across the boreal forest? Journal of Chemical Ecology, 39: 1209-1220.

MacQuarrie, C.J.K. and Cooke, B.J. 2011. Densitydependent population dynamics of mountain pine beetle in thinned and unthinned stands. Canadian Journal of Forest Research-Revue Canadienne de Recherche Forestiere, 41: 1031-1046.

Maness, H., Kushner, P.J., and Fung, I. 2013. Summertime climate response to mountain pine beetle disturbance in British Columbia. Nature Geoscience, 6: 65-70.

Massey, C.L. and Wygant, N.D. 1954. Biology and control of the Engelmann spruce beetle in Colorado. Circular 944. United States Department of Agriculture, Forest Service, Washington, District of Columbia, United States of America.

McCambridge, W.F. and Knight, F.B. 1972. Factors affecting spruce beetles during a small outbreak. Ecology, 53: 830-839.

McKee, F.R. 2015. Biology and population dynamics of the eastern larch beetle, Dendroctonus simplex LeConte, and its interactions with eastern larch (tamarack), Larix laricina. $\mathrm{PhD}$ Dissertation. University of Minnesota, Minneapolis, Minnesota, United States of America. Available from https:// conservancy.umn.edu/handle/11299/175514 [accessed 2 January 2016]. 
McKee, F.R. and Aukema, B.H. 2015a. Influence of temperature on the reproductive success, brood development, and brood fitness of the eastern larch beetle, Dendroctonus simplex LeConte. Agricultural and Forest Entomology, 17: 102-112.

McKee, F.R. and Aukema, B.H. 2015b. Successful reproduction by the eastern larch beetle (Coleoptera: Curculionidae) in the absence of an overwintering period. The Canadian Entomologist, 147: 602-610.

McKee, F.R., Huber, D.P.W., and Aukema, B.H. 2013. Comparisons of mountain pine beetle (Dendroctonus ponderosae Hopkins) reproduction within a novel and traditional host: effects of insect natal history, colonized host species and competitors. Agricultural and Forest Entomology, 15: $310-320$.

McMullen, L.H. and Atkins, M.D. 1961. Intraspecific competition as a factor in the natural control of the Douglas-fir beetle. Forest Science, 7: 197-203.

Miller, M.C., Moser, J.C., McGregor, M., Gregoire, J.-C., Baiser, M., Dahlsten, D.L., et al. 1987. Potential for biological control of native North American Dendroctonus beetles (Coleoptera: Scolytidae). Annals of the Entomological Society of America, 80: $417-428$.

Negrón, J.F. 1998. Probability of infestation and extent of mortality associated with the Douglas-fir beetle in the Colorado Front Range. Forest Ecology and Management, 107: 71-85.

Negrón, J.F., Anhold, J.A., and Munson, A.S. 2001. Within-stand spatial distribution of tree mortality caused by the Douglas-fir beetle (Coleoptera: Scolytidae). Environmental Entomology, 30: 215-224.

Negrón, J.F., Schaupp, W.C., Gibson, K.E., Anhold, J., Hansen, D., Thier, R.W., et al. 1999. Estimating extent of mortality associated with the Douglas-fir beetle in the central and northern Rockies. Western Journal of Applied Forestry, 14: 121-127.

Nicholson, A.J. 1954. An outline of the dynamics of animal populations. Australian Journal of Zoology, 2: 9-65.

Öhrn, P., Långström, B., Lindelöw, Å., and Björklund, N. 2014. Seasonal flight patterns of Ips typographus in southern Sweden and thermal sums required for emergence. Agricultural and Forest Entomology, 16: $147-157$.

Ohsawa, M., Langor, D., Hiratsuka, Y., and Yamaoka, Y. 2000. Fungi associated with Dendroctonus rufipennis and Polygraphus rufipennis, and white spruce inoculation tests. Canadian Journal of Plant Pathology, 22: 254-257.

Økland, B. and Bjørnstad, O.N. 2006. A resourcedepletion model of forest insect outbreaks. Ecology, 87: 283-290.

Poland, T.M. and Borden, J.H. 1997. Attraction of a bark beetle predator, Thanasimus undatulus (Coleoptera: Cleridae), to pheromones of the spruce beetle and two secondary bark beetles (Coleoptera: Scolytidae). Journal of the Entomological Society of British Columbia, 94: 35-41.
Powell, J.A., Jenkins, J.L., Logan, J.A., and Bentz, B.J. 2000. Seasonal temperature alone can synchronize life cycles. Bulletin of Mathematical Biology, 62: 977-998.

Powers, J.S., Sollins, P., Harmon, M.E., and Jones, J.A. 1999. Plant-pest interactions in time and space: a Douglas-fir bark beetle outbreak as a case study. Landscape Ecology, 14: 105-120.

Prebble, M.L. 1933. The larval development of three bark beetles. The Canadian Entomologist, 65: 145-150.

Prebble, M.L. 1951. Forest entomology in relation to silviculture in Canada. Forest Chronicle, 27: 8-37.

Prebble, M.L. 1955. Entomology in relation to forest protection in Canada. Forest Chronicle, 31: 314-323.

Preisler, H.K., Hicke, J.A., Ager, A.A., and Hayes, J.L. 2012. Climate and weather influences on spatial temporal patterns of mountain pine beetle populations in Washington and Oregon. Ecology, 93: 2421-2434.

Raffa, K.F. 2001. Mixed messages across multiple trophic levels: the ecology of bark beetle chemical communication systems. Chemoecology, 11: 49-65.

Raffa, K.F., Aukema, B.H., Bentz, B.J., Carroll, A.L., Hicke, J.A., Turner, M.G., et al. 2008. Cross-scale drivers of natural disturbances prone to anthropogenic amplification: The dynamics of bark beetle eruptions. Bioscience, 58: 501-517.

Raffa, K.F. and Berryman, A.A. 1983. The role of host plant resistance in the colonization behavior and ecology of bark beetles (Coleoptera: Scolytidae). Ecological Monographs, 53: 27-49.

Rankin, L.J. and Borden, J.H. 1991. Competitive interactions between the mountain pine beetle and the pine engraver in lodgepole pine. Canadian Journal of Forest Research, 21: 1029-1036.

Richmond, H.A. 1986. Forest entomology: from packhorse to helicopter. Pest Management Report Number 8. British Columbia Ministry of Forests and Lands, Victoria, British Columbia, Canada.

Robertson, C., Nelson, T.A., Jelinski, D.E., Wulder, M. A., and Boots, B. 2009. Spatial-temporal analysis of species range expansion: the case of the mountain pine beetle, Dendroctonus ponderosae. Journal of Biogeography, 36: 1446-1458.

Robertson, I.C. 2000. Reproduction and developmental phenology of Ips perturbatus (Coleoptera: Scolytidae) inhabiting white spruce (Pinaceae). The Canadian Entomologist, 132: 529-537.

Rose, A.H. and Lindquist, O.H. 1980. Insects of eastern larch, cedar, and juniper. Forestry Technical Report 28. Environment Canada, Canadian Forestry Service, Great Lakes Forest Research Centre, Sault Ste. Marie, Ontario, Canada.

Ross, D.W. and Wallin, K.F. 2008. High release rate 3-methylcyclohex-2-en-1-one dispensers prevent Douglas-fir beetle (Coleoptera: Curculionidae) infestation of live Douglas-fir. Journal of Economic Entomology, 101: 1826-1830. 
Rousseau, J., Bauce, E., Lavallee, R., and Guertin, C. 2012. Winter mortality and supercooling point of the spruce beetle (Coleoptera: Curculionidae) not affected by host tree vigor in Nova Scotia, Canada. Journal of the Acadian Entomological Society, 8: 1-10.

Royama, T. 1984. Population dynamics of the spruce budworm Choristoneura fumiferana. Ecological Monographs, 54: 429-462.

Rudinsky, J.A. 1966. Host selection and invasion by the Douglas-fir beetle, Dendroctonus pseudotsugae Hopkins, in coastal Douglas-fir forests. The Canadian Entomologist, 98: 98-111.

Safranyik, L. 2011. Development and survival of the spruce beetle, Dendroctonus rufipennis, in stumps and windthrow. Information Report BC-X-430. Natural Resources Canada, Canadian Forest Service, Pacific Forestry Centre, Victoria, British Columbia, Canada.

Safranyik, L. and Carroll, A.L. 2006. The biology and epidemiology of the mountain pine beetle in lodgepole pine forests. In The mountain pine beetle: a synthesis of biology, management, and impacts on lodgepole pine. Edited by L. Safranyik and B. Wilson. Natural Resources Canada, Pacific Forestry Centre, Victoria, British Columbia, Canada. Pp. 3-66.

Safranyik, L., Carroll, A.L., Régnière, J., Langor, D.W., Riel, W.G., Shore, T.L., et al. 2010. Potential for range expansion of mountain pine beetle into the boreal forest of North America. The Canadian Entomologist, 142: 415-442.

Safranyik, L. and Linton, D.A. 1985. Influence of competition on size brood production and sex ratio in spruce beetles (Coleoptera: Scolytidae). Journal of the Entomological Society of British Columbia, 82: 52-56.

Safranyik, L. and Linton, D.A. 1999. Spruce beetle (Coleoptera: Scolytidae) survival in stumps and windfall. The Canadian Entomologist, 131: 107-113.

Safranyik, L., Shrimpton, D.M., and Whitney, H.S. 1974. Management of lodgepole pine to reduce losses from the mountain pine beetle. Forestry Technical Report 1. Environment Canada, Canadian Forestry Service, Pacific Forest Research Centre, Victoria, British Columbia, Canada.

Safranyik, L., Shrimpton, D.M., and Whitney, H.S. 1975. An interpretation of the interaction between lodgepole pine, the mountain pine beetle and its associated blue stain fungi in western Canada. In Management of lodgepole pine ecosystems. Edited by D.M. Baumgartner. Washington State University Cooperative Extension Service, Pullman, Washington, United States of America. Pp. 406-428.

Safranyik, L., Shrimpton, D.M., and Whitney, H.S. 1983. The role of host-pest interaction in population dynamics of Dendroctonus rufipennis (Kirby) (Coleoptera: Scolytidae). In The role of insect-plant relationships in the population dynamics of forest pests, Proceedings of the International Union of Forestry Research Organizations, Program on Man and Biosphere Symposium. August 24-28, 1981, Irkutsk. USSR. Edited by A.S. Isaev. Union of Soviet Socialist Republics Academy of Sciences. Pp. 197-212.
Sahota, T.S. and Ibaraki, A. 1979. Effect on tree activity on the rate of yolk protein deposition in Dendroctonus rufipennis (Coleoptera: Scolytidae). The Canadian Entomologist, 111: 1319-1323.

Sahota, T.S., Peet, F.G., and Ibaraki, A. 1987. Manipulations of egg-gallery length to vary brood density in spruce beetle Dendroctonus rufipennis (Coleoptera: Scolytidae): effects on brood survival and quality. Journal of Entomology, 84: 59-63.

Sahota, T.S. and Thomson, A.J. 1979. Temperature induced variation in the rates of reproductive processes in Dendroctonus rufipennis (Coleoptera: Scolytidae): a new approach to detecting changes in population quality. The Canadian Entomologist, 111: 1069-1078.

Sambaraju, K.R., Carroll, A.L., Zhu, J., Stahl, K., Moore, R.D., and Aukema, B.H. 2012. Climate change could alter the distribution of mountain pine beetle outbreaks in western Canada. Ecography, 35: 211-223.

Schmid, J.M. and Frye, R.H. 1977. Spruce beetle in the Rockies. General Technical Report RM-49. Rocky Mountain Forest and Range Experiment Station, United States Department of Agriculture Forest Service, Fort Collins, Colorado, United States of America.

Schmitz, R.F. and Gibson, K.E. 1996. Douglas-fir beetle. Forest Insect \& Disease Leaflet 5. United States Department of Agriculture, Forest Service, Washington, District of Columbia, United States of America.

Schmitz, R.F. and Rudinsky, J.A. 1968. Effect of competition on survival in western Oregon of the Douglas-fir beetle. Research Paper 8. School of Forestry, Oregon State University, Corvallis, Oregon, United States of America.

Seybold, S.J., Albers, M.A., and Katovich, S.A. 2002. Eastern larch beetle. Forest Insect \& Disease Leaflet 175. United States Department of Agriculture Forest Service, Northern Research Station, St. Paul, Minnesota, United States of America.

Sherriff, R.L., Berg, E.E., and Miller, A.E. 2011. Climate variability and spruce beetle (Dendroctonus rufipennis) outbreaks in south-central and southwest Alaska. Ecology, 92: 1459-1470.

Shore, T.L., Safranyik, L., and Riel, W.G. 1999. Evaluation of factors affecting tree and stand susceptibility to the Douglas-fir beetle (Coleoptera: Scolytidae). The Canadian Entomologist, 131: 831-839.

Simpson, L.J. 1929. The biology of Canadian bark beetles. The seasonal history of Dendroctonus simplex LeC. The Canadian Entomologist, 61: 274-279.

Six, D.L. 2013. The bark beetle holobiont: why microbes matter. Journal of Chemical Ecology, 39: 989-1002.

Six, D.L. and Bentz, B.J. 2003. Fungi associated with the North American spruce beetle, Dendroctonus rufipennis. Canadian Journal of Forest Research, 33: 1815-1820.

Six, D.L. and Bracewell, R. 2015. Dendroctonus. In Bark beetles: Biology and ecology of native and invasive species, 1 st edition. Edited by F.E. Vega and R.W. Hofstetter. Elsevier, London, United Kingdom. Pp. 305-350. 
Smith, G.D., Carroll, A.L., and Lindgren, B.S. 2011. Facilitation in bark beetles: endemic mountain pine beetle gets a helping hand. Agricultural and Forest Entomology, 13: 37-43.

Solheim, H. and Krokene, P. 1998. Growth and virulence of Ceratocystis rufipenni and three bluestain fungi isolated from the Douglas-fir beetle. Canadian Journal of Botany, 76: 1763-1769.

Sun, J., Lu, M., Gillette, N.E., and Wingfield, M.J. 2013. Red turpentine beetle: innocuous native becomes invasive tree killer in China. Annual Review of Entomology, 58: 293-311.

Swaine, J.M. 1911. Some insects of larch. Annals of the Entomological Society of Ontario, 41: 81-88.

Swaine, J.M. 1918. Canadian bark-beetles. Part II. A preliminary classification, with an account of the habits and means of control. Dominion of Canada, Department of Agriculture, Entomological Branch, Technical Bulletin, 14: 1-143.

Swaine, J.M. 1929. Forest insect investigations in Canada 1928. Forestry Chronicle, 5: 35-41.

Taerum, S.J., Duong, T.A., de Beer, Z.W., Gillette, N., Sun, J.-H., Owen, D.R., et al. 2013. Large shift in symbiont assemblage in the invasive red turpentine beetle. Public Library of Science One, 8(10): e78126. doi:10.1371/journal.pone.0078126.

Tailleux, I. and Cloutier, C. 1993. Defoliation of tamarack by outbreak populations of larch sawfly in subarctic Quebec: measuring the impact on tree growth. Canadian Journal of Forest Research, 23: 1444-1452.

Taylor, A.D., Hayes, J.L., Roton, L., and Moser, J.C. 1992. A phloem sandwich allowing attack and colonization by bark beetles (Coleoptera, Scolytidae) and associates. Journal of Entomological Science, 27: 311-316.

Thomson, A.J. and Sahota, T.S. 1981. Competition and population quality in Dendroctonus rufipennis (Coleoptera: Scolytidae). The Canadian Entomologist, 113: $177-183$.

Tsui, C.K.-M., Farfan, L., Roe, A.D., Rice, A.V., Cooke, J.E.K., El-Kassaby, Y.A., et al. 2014. Population structure of mountain pine beetle symbiont Leptographium longiclavatum and the implication on the multipartite beetle-fungi relationships. Public Library of Science One, 9(8): e105455. doi:10.1371/journal.pone.0105455.

Venette, R.C. and Walter, A.J. 2008. Connecting overwintering success of eastern larch beetle to health of tamarack. In Forest health monitoring: 2008 national technical report. Edited by K.M. Potter and B.L. Conkling. General Technical Report SRS-158. United States Department of Agriculture Forest Service, Southern Research Station, Ashville, North Carolina, United States of America. Pp. 167-169.

Vite, J.P., Pitman, G.B., Fentiman, A.F., and Kinzer, G.W. 1972. 3-methyl-e-cyclohexen-1-ol isolated from Dendroctonus. The Science of Nature - Naturwissenschaften, 59: 469.
Wallin, K.F. and Raffa, K.F. 2004. Feedback between individual host selection behavior and population dynamics in an eruptive herbivore. Ecological Monographs, 74: 101-116.

Waring, R.H. and Pitman, G.B. 1980. A simple model of host resistance to bark beetles. Oregon State University, Forest Research Laboratory, Research Note, 65: 1-2.

Webb, W.L. and Karchesy, J.J. 1977. Starch content of Douglas-fir defoliated by the tussock moth. Canadian Journal of Forest Research, 7: 186-188.

Weed, A.S., Ayres, M.P., and Bentz, B.J. 2015. Population dynamics of bark beetles. In Bark beetles: biology and ecology of native and invasive species, 1st edition. Edited by F.E. Vega and R.W. Hofstetter. Elsevier, London, United Kingdom. Pp. 157-208.

Weed, A.S., Ayres, M.P., and Hicke, J.A. 2013. Consequences of climate change for biotic disturbances in North American forests. Ecological Monographs, 83: 441-470.

Werner, R.A. 1986. The eastern larch beetle in Alaska. Research Paper PNW-357. United States Department of Agriculture, Forest Service, Pacific Northwest Research Station, Fairbanks, Alaska, United States of America.

Werner, R.A. 1995. Toxicity and repellency of 4-allylanisole and monoterpenes from white spruce and tamarack to the spruce beetle and eastern larch beetle (Coleoptera: Scolytidae). Environmental Entomology, 24: 372-379.

Werner, R.A. and Illman, B.L. 1994. Response of Lutz, Sitka, and white spruce to attack by Dendroctonus rufipennis (Coleoptera: Scolytidae) and blue stain fungi. Environmental Entomology, 23: 472-478.

Williamson, R.L. and Price, F.E. 1971. Initial thinning effects in 70- to 150-year-old Douglas-fir - western Oregon and Washington. Research Paper PNW-117. United States Department of Agriculture - Forest Service, Pacific Northwest Forest and Range Experiment Station, Portland, Oregon, United States of America.

Wood, S.L. 1969. New synonymy and records of Platypodidae and Scolytidae (Coleoptera). Great Basin Naturalist, 29: 113-128.

Wood, S.L. 1982. The bark and ambrosia beetles of North and Central America (Coleoptera: Scolytidae), a taxonomic monograph. Great Basin Naturalist Memoirs, 6: 1-1359.

Work, T.T., McCullough, D.G., Cavey, J.F., and Komsa, R. 2005. Arrival rate of nonindigenous insect species into the United States through foreign trade. Biological Invasions, 7: 323-332.

Wright, L.C., Berryman, A.A., and Wickman, B.E. 1984. Abundance of the fir engraver, Scolytus ventralis, and the Douglas-fir beetle, Dendroctonus pseudotsugae, following tree defoliation by the Douglas-fir tussock moth, Orgyia pseudotsugata. The Canadian Entomologist, 116: 293-305.

Yan, Z.L., Sun, J.H., Don, O., and Zhang, Z.N. 2005. The red turpentine beetle, Dendroctonus valens LeConte (Scolytidae): an exotic invasive pest of pine in China. Biodiversity \& Conservation, 14: 1735-1760. 